\title{
Barriers to access to opioid medicines: results of a review of national legislation and regulations of 11 Central and Eastern European countries
}

Marjolein J. M. Vranken ${ }^{1}$, John Lisman ${ }^{2}$, Aukje K. Mantel-Teeuwisse ${ }^{1}$, Saskia Jünger ${ }^{3}$, Willem

Scholten ${ }^{4}$, Lukas Radbruch ${ }^{5 a, 5 b}$, Sheila Payne ${ }^{6}$, Marie-Hélène D. B. Schutjens ${ }^{1,7}$

\section{Affiliations}

1. Utrecht Institute for Pharmaceutical Sciences, Division of Pharmacoepidemiology \& Clinical Pharmacology, Utrecht University, Utrecht, the Netherlands

2. Lisman Legal Life sciences, Nieuwerbrug, The Netherlands

3. Institute of General Practice, Hannover Medical School, Hannover, Germany

4. Willem Scholten, Willem Scholten Consultancy, Lopik, The Netherlands

5a. Department of Palliative Medicine, University Hospital Bonn, Germany

5b. Centre for Palliative Care, Malteser Hospital Bonn, Bonn, Germany

6. International Observatory on End of Life Care, Division of Health Research, Lancaster University, Lancaster, United Kingdom

7. Schutjens de Bruin, Tilburg, The Netherlands

\section{Number of words (excl. abstract, references, tables and figures): 4109}

\section{Number of tables and figures: $\quad 5+2$ supplementary annexes}

Corresponding author: Aukje K. Mantel-Teeuwisse

Utrecht Institute for Pharmaceutical Sciences, Division

Pharmacoepidemiology \& Clinical Pharmacology, PO Box 80 082, 3508 TB Utrecht, The Netherlands

Tel: +31 302537324 / Email: A.K.Mantel@uu.nl 


\section{Summary}

Control measures designed to prevent abuse of opioid medicines often unintentionally restrict legitimate medical use, leaving millions of patients with cancer in pain. This study aimed to develop and validate an assessment instrument based on the WHO Policy Guidelines, and subsequently to systematically identify legal and regulatory barriers to access to opioids in 11 European countries using this instrument. Relevant legislation and regulations were independently reviewed by three reviewers. Potential barriers were found in all countries, varying from 22 to 132 per country and varying from 1 to 49 per single category. Individual differences in the level of impediment were shown (for example: prescription validity ranging between 5 days and 13 weeks). The results of this review should give rise to a critical national review and revision of provisions that may impede access to opioids in a way that is disproportional to their benefit for the prevention of abuse.

\section{Introduction}

Opioid analgesics are indispensable for the treatment of moderate to severe cancer pain. ${ }^{1}$ The World Health Organization (WHO) has recognised this medical need by adding morphine to the 'WHO Model List of Essential Medicines': ${ }^{2}$ medically necessary medicines that should be available in sufficient quantity at an affordable price. Despite this internationally acknowledged medical need, at least $79 \%$ of the world population has no or very low to low access to opioid medicines for pain relief. ${ }^{3}$ The WHO estimates that on a global level 5.5 million terminal cancer patients suffer moderate to severe pain due to inadequate access to controlled medicines. ${ }^{4} \mathrm{~A}$ variety of factors is considered to contribute to inadequate access including economic aspects, legislation and policy, lack

of knowledge and societal attitudes. ${ }^{4-6}$ The latter three factors are strongly interrelated: lack of knowledge and misconceptions about opioids in itself contribute to fear of using opioid medicines in medical practice and hence may restrict access to these medicines. 
Additionally, this misguided fear may cause governments and policy makers to implement restrictive policies and legislation. These restrictive policies and legislation in turn foster fear of using opioid medicines, in particular if severe sanctions are involved for unintended violations of these legislation and policies. As a result of this complex interaction of factors influencing access, patients worldwide suffer pain and other concomitant clinical consequences that impair the quality of life, such as physical, psychosocial and psychological malfunctioning. ${ }^{7}$

While other factors as described above are also relevant, legal and regulatory control measures are considered to play an important role in the global problem of inadequate access. . $^{8,9,6,5,10,11,12}$ Opioid medicines are controlled under the international agreement 'the Single Convention on Narcotic Drugs'.${ }^{13}$ Parties to this Single Convention on Narcotic Drugs are obliged to take measures to prevent abuse and diversion by limiting the use of these controlled medicines to medical and scientific purposes. Despite (inter)national control measures, satisfactory levels of prevention of abuse and diversion are not always achieved which may result in further control actions. ${ }^{14}$ In New York City for example, in response to a progressive increase in overdose and deaths from opioid medicines, clinical guidelines were established limiting the prescribing of opioid analgesics in emergency departments to a 3-day treatment period ${ }^{15}$ and excluding the prescribing of some long-acting opioid analgesics. ${ }^{14}$ These control measures may sometimes be necessary to reduce risks associated with abuse and diversion, although there is little high quality evidence to support this. In the United States for example, strategies focussing on patient and prescriber information showed to be useful to (moderately) decrease opioid over-prescribing and diversion. ${ }^{16}$ However, the problems and also the solutions in the United Stated are very specific and are not comparable to the situation in many other countries across the world. ${ }^{17}$ These measures may not reduce abuse and diversion in countries where there is no over-prescribing and where there is a different mechanism behind abuse and diversion.

Although implementation of more strict control measures may result in prevention of abuse and diversion, the downside is that legitimate medical use may also 
be restricted. As a result, access to opioid medicines is inadequate for millions of patients that rely on their use including patients with moderate to severe cancer pain. Numerous studies have reported on legal and regulatory barriers to access to opioid analgesics, mostly in low and middle income countries. Strict control measures were considered burdensome and complex and were deemed to interfere with medical practice. ${ }^{10}$ Frequently reported legal and regulatory restrictions to access include the requirement for permission to prescribe or receive opioids, limitations on the amount to be prescribed, restrictions regarding dispensing privileges and the absence of emergency provisions. ${ }^{9,18-21}$

Where on an international level the prevention of abuse and diversion has prevailed for decades, more recently this focus has shifted towards ensuring access to essential medicines. In this context, governments were urged by the International Narcotics Control Board and other international organisations and agencies to critically examine their national policies and legislations and remove impediments to the adequate availability of opioid medicines for medical and scientific purposes. ${ }^{10,22,23}$ Governments that now implement control measures are facing a dilemma in their efforts to achieve maximum public health outcome: how to prevent opioid abuse while not negatively impacting access to opioid medicines for patients in medical need?

An instrument was developed to support government representatives and policy makers in evaluating their national policies and legislation: the WHO Policy Guidelines 'Ensuring balance in national policies on controlled substances: Guidance for availability and accessibility of controlled medicines' (hereinafter: WHO Policy Guidelines). ${ }^{4}$ These guidelines were updated at the start of the Access to Opioid Medication in Europe (ATOME) project; a project that aimed to improve access to medication in twelve Central and Eastern European countries with statistical evidence of very low morphine consumption per capita and no major ongoing initiatives to improve access to opioid medicines (Bulgaria, Cyprus, Estonia, Greece, Hungary, Latvia, Lithuania, Poland, Serbia, Slovakia, Slovenia and Turkey). Although the WHO Policy Guidelines give direction and include an assessment checklist, there is no practical assessment instrument available 
with detailed information on potential barriers to evaluate legislation and regulations. The aim of this study was therefore twofold: (1) to develop and validate an assessment instrument for the systematic analysis of national legislation and regulations; and (2) to conduct a review using the instrument with the objective to identify potential legal and regulatory barriers to access to opioid medicines in eleven of the twelve countries participating in the ATOME project (all countries except Poland).

\section{Methods}

\section{Selection of national legislation and regulations}

The ATOME review of national legislation and regulations consisted of a two-step method: a quick scan of legislation ${ }^{24}$ provided a basis for a more thorough review. At the start of the ATOME project, country teams were composed based on their expertise and role in their country to ensure relevance to the project activities. These country teams included representatives from the national controlled substances authorities and national Ministries of Health, experts representing regulatory and law enforcement authorities and leading healthcare professionals and patient representatives. Within these country teams a legal expert was appointed to collaborate on the ATOME legislation review. Eleven of the twelve countries participated in the ATOME legislation review; the Poland ATOME country team decided not to participate and was therefore not included in this legislation review.

Key experts in each country selected legislation concerning controlled substances and opioid medicines for the quick scan in the period the period March November 2011. This quick scan consisted of the identification of obvious impediments in selected legal documents using eight of the 21 WHO Guidelines. In the framework of the more thorough review, the key experts in the selected countries were requested to update information about the legislation and provide information on forthcoming changes in the originally selected legislation. Initially collected and additional relevant legislation and regulations (collected until February 2013) were translated into English 
by a translation agency (NOVA Language Services, Barcelona, Spain) if it was only available in the national language (see supplementary annex 1 for a full overview of selected and translated legislation and regulations).

\section{Analysis of national legislation and regulations}

In order to review legislation and regulations, a method was developed using an assessment instrument with potential barriers to access to opioid medicines focusing on nine different categories: prescribing; dispensing; manufacturing; usage; trade and distribution; affordability; penalties; language; and other (to include potential barriers that did not fit into one of the other categories). The assessment instrument was developed by authors JL, MHS and MV based on the WHO Policy Guidelines and additional literature regarding barriers to access. ${ }^{4,8,25-27} \mathrm{~A}$ selection of sub-categories (referred to as items) of potential barriers in the category prescribing and language is provided in Table 1.

All relevant national legislation and regulations were analysed by one reviewer (author MV) and legal or regulatory provisions related to controlled substances and opioid medicines were selected for further review. These selected provisions were subsequently independently reviewed by three reviewers (authors $\mathrm{JL}$, MHS and MV) using the assessment instrument and potential barriers to access to opioid medicines were identified. Differences of views between the reviewers regarding the identification of potential barriers were discussed until consensus was reached. Newly identified barriers were added to the assessment instrument and the reviewed legislation and regulations were checked retrospectively to complete the process.

\section{Validation of methods and results}

The reliability of the selection of provisions for further review by one reviewer (author MV) was validated by assessing the inter-rater reliability of the selection of provisions between two reviewers (authors MHS and MV) for a selected number of countries. The controlled substances law of three randomly selected countries (Hungary, 
Serbia and Slovakia) was reviewed by the two reviewers and provisions were independently selected for further review. The selection by the two reviewers was compared using Cohen's kappa statistics and was rated to be very good (kappa= 0.87). Following validation of the selection of provisions, the assessment instrument was piloted by all three reviewers to align the review process: selected provisions of one country (Greece) were analysed based on the assessment instrument and the three reviewers met to discuss differences of views which concerned general interpretation of the assessment instrument.

Individual country reports containing the provisional results of the analysis of national legislation and regulations were disseminated to the ATOME country teams and discussed during the ATOME legislation review workshop in Utrecht, the Netherlands. ${ }^{28}$ In total 14 representatives from nine of the eleven countries participating in the ATOME project (all countries except Bulgaria and Turkey) attended the meeting. Additionally, the country teams were invited to provide feedback in writing, using a feedback form that addressed several questions, including the correctness of the translation and the results (see supplementary annex 2). Feedback in writing was received from six of the eleven countries. Small changes were made to the results based on feedback received regarding small errors in translation, recent amendments in legislation or differences in interpretation of definitions and/or terminology. The changes did not lead to modification of the assessment instrument.

\section{Data analysis}

The total number of initially selected provisions was calculated per country and in total. Additionally, the total number of provisions that was considered to contain at least one potential barrier to access to opioid medicines was assessed in relation to the total number of provisions selected for review (per country and in total). Potential barriers were identified according to category and according to item within the categories (all categories except 'language'). The presence of potential barriers in the category language was recorded qualitatively according to item to correct for language 
repetitions. Individual differences between the countries were highlighted for the following items: limited prescription validity, special prescription forms required, multiple copies required, amount of controlled medicine to be prescribed is limited and daily dosage is limited.

\section{Results}

\section{Potential barriers identified}

In total, 925 provisions were initially selected for further review (author MV) varying from 35 provisions (Cyprus) to 144 provisions (Lithuania). A total of $86 \%$ of the initially selected provisions were considered to contain at least one potential barrier (including category 'language'), ranging from 72\% (Serbia) to 98\% (Slovenia). Potential barriers to access were found in all eleven countries with the number of categories where items were found varying between six (Slovenia) to all (Bulgaria \& Latvia) of the nine categories (Figure 1). In total, 778 potential barriers (excluding the category language) were identified in eleven countries, with the smallest number in Cyprus $(n=22)$ and the largest number in Lithuania $(n=128)$. Each country showed potential barriers in the categories 'prescribing', 'dispensing' and 'usage', while the total number of barriers in each category varied from 1 (several countries, several categories) to 49 (Greece, prescribing) (Figure 1). Most barriers were identified for the prescribing and dispensing of opioid medicines, ranging from 5 (Cyprus) to 14 (Latvia) of the 20 items (see Table 2).

Individual differences in barriers to access (categories prescribing and dispensing)

Prescribing and dispensing restrictions and administrative requirements were the most common barriers identified in the categories 'prescribing' and 'dispensing', with individual differences in the level of impediment (Table 3). For example, the prescription validity varied from 5 days to 13 weeks, and special prescription forms were used in duplicate and triplicate. Restrictions regarding the total amount to be prescribed on a single prescription were identified in the legislation of several countries with 
quantifications in the number of treatment days or by weight. Additional restrictions regarding the daily dosage were identified in the legislation of three countries.

\section{Examples of provisions identified}

Other potential barriers in the category of prescribing included requirements for a permit or license, restrictions regarding the authorisation to prescribe, administrative requirements and requirements for the storage of controlled medicines or prescription forms (see Table 2). Potential barriers in the category of dispensing included limitations regarding the pharmacies that are authorised to dispense, limitations on the dispensing on (designated) controlled medicines, administrative requirements, storage requirements and delivery restrictions. Besides the frequently reported prescribing and dispensing restrictions, potential barriers also include strict requirements for accessing education on controlled medicines, disproportional punitive sanctions for healthcare professionals, geographical restrictions to accessing opioid medicines, the violation of the privacy of patients and strict requirements for the storage of controlled medicines during international transportation (see Table 2).

\section{Language in legislation and regulations}

The legislation in all eleven countries referred to (patients with) dependence in a disrespectful manner (Table 4). Ten countries (all except Hungary) used incorrect definitions and/or unclear language in their legislation. These ten countries also had provisions in their legislation that do not make a clear distinction between medical use and illicit use or abuse. See Table 1 for examples of potential barriers in the category of language including an explanation.

\section{Discussion}

This study shows that the reviewed national legislation and regulations contain many potential barriers to access to opioid medicines that are indispensable for the management of cancer pain. Additionally, the study shows that all countries assessed 
were considered to have language in their legislation that contributes to the stigmatisation of the use of opioid medicines. Most potential barriers concerned the prescribing and dispensing of opioid medicines, with individual differences in the level of impediment of several important items, such as limitations concerning the prescription validity, treatment duration and daily dosage. While legal and regulatory barriers to access to opioids have previously been identified by others, this is the first study showing detailed insight in the qualitative aspects of potential barriers by a systematic external review of legislation taken into account all elements in the pharmaceutical supply chain (from manufacturing to usage) and by using a newly developed assessment instrument based on the WHO Policy Guidelines ${ }^{4}$ that can be used in an universal manner by others.

Other studies describing legal, regulatory or policy barriers to access to opioid medicines either conducted a survey ${ }^{18-21,25,29,30,22}$ or evaluated legislation and policies building on similar content as the WHO Policy Guidelines. ${ }^{31,27,26}$ Regulatory barriers to the accessibility of opioids for cancer pain in Central and Eastern Europe were previously reported by Cherny et al. based on surveys distributed among senior clinicians in the period 2007-2009. ${ }^{25}$ Results that were similar to the results of the current study were found concerning reported limitations on the treatment period and the requirement to use special forms or prescribe in multiple copies. Small differences between findings may be associated with the high level of detail in the present review and the availability of information on recent amendments. Different results were seen regarding the use of stigmatising language in legislation, which may be the result of underreporting by the survey's respondents. A worldwide follow up of the European survey by Cherny et al. revealed that regulatory barriers and restricted formularies also play an important role in inadequate access to opioid medicines for the treatment of cancer pain in Africa, Asia, Latin America, the Caribbean and the Middle East, affecting hundreds of millions of patients. ${ }^{18-21,29,30}$ While the focus of both abovementioned surveys - and most other studies - was restricted to a predefined subset of potential barriers, the scope of our study allowed for identification of every potential barrier encountered by systematically 
reviewing all selected legislation. Due to this broad and systematic approach potential hurdles to accessing opioids were also located in less obvious areas. Additional research is needed to refine the assessment instrument and to assess the intention of the respective legal provisions and their impact on access in clinical practice.

Several limitations of the present external review of legislation should be mentioned. First of all, legal and regulatory data were analysed based on the selection made by key experts in the specific countries and in many cases after translation into English. Both incorrect translation and incomplete selection of documents may have caused incomplete or incorrect reporting of potential barriers. By training and guidance of carefully selected key experts and by following a two-step method with an additional update of legal and regulatory text, the omission of data was minimised. Inconsistencies in translation were reduced as much as possible by working with a professional translation agency, specialised in the area of law and health and by dissemination of the results to the ATOME country teams with the explicit request to provide feedback on errors in translation. Secondly, as the methods of this study comprised an analysis of legal text, inevitably variation of interpretation may occur. By involving three reviewers and by determining the general interpretation of the assessment instrument the chance of divergent interpretations has been minimised.

This external review of national legislation was not only shown to be useful for the identification of potential barriers, but the detailed level of information on these potential barriers has led to specific recommendations for improvement as a part of the ATOME project. Several participating countries have already implemented some of these recommendations. For example in Lithuania, the total number of special prescription forms physicians are allowed to receive has been doubled from 10 to 20 forms. In Estonia, the requirement for pharmacies to obtain a special permit which makes them authorised to dispense controlled medicines was removed. Due to this requirement, pharmacies were reluctant to apply for a license with the result that patients had difficulties identifying a pharmacy that could dispense their opioid medicines. ${ }^{32}$ Although all these examples are considered to contribute to better access 
to opioids for patients, the impact of these revisions on clinical practice has not been assessed and therefore remains unknown. Additional research is recommended to assess the impact of lifting potential barriers in these countries. Additional research is also needed to assess the level of impact of different types of barriers as it can be assumed that some types of barriers are more likely to influence access than others. Finally, scientific data are also needed in a broader context to gain insight in how a restrictive control system exerts impact on access to opioid analgesics in comparison to a very liberal system. So far only anecdotal evidence exists showing a direct correlation between strict prescribing or dispensing requirements and patients being denied adequate pain treatment. ${ }^{33,34}$ Society would benefit from solid data showing how we can achieve less drug related risks and better clinical outcomes for patients with moderate to severe cancer pain by optimising legislation and regulations.

In conclusion, the potential barriers identified by this external review of national legislation give rise to a critical national review and revision of provisions that impede access to opioid medicines for patients with cancer pain in a way that is disproportional to their (intended) benefit for the prevention of abuse and diversion. To provide a legal framework that focuses on access to opioid medication with maximum health outcome, these revisions should take place in consultation with healthcare professionals and patient organisations. Several countries participating in the ATOME project are already in the process of revising legislation and implementing recommendations for improvement, bringing patients in medical need one step closer towards adequate access to opioid medicines.

\section{Search strategy and selection criteria}

A literature search was done in PubMed and Google Scholar to identify relevant publications published in English language. We used the following keywords in titles or abstracts: "barriers" OR "impediment's" combined with the search terms "legislation" OR "legal" OR "regulation(s)" combined with the search terms "opioids" OR "opioid medicines" OR "opioid analgesic(s)" OR "narcotic drug(s)". The search was not limited to 
year of publication. The relevance of the publications was determined by a preliminary review of the abstracts. In addition to the electronic search using keywords, the reference list of relevant documents were also searched to identify additional relevant publications.

\section{Funding}

The research leading to these results has received funding from the European Community's Seventh Framework Programme [FP7/2007-2013] under grant agreement $n^{\circ} 222994$ with the overall aim to improve the access to opioid medication in Europe.

\section{Contributors}

This study took place following a grant application for the Access To Opioid Medication in Europe (ATOME) project, which started under the 7th Framework Programme of the European Community. WS conceived the idea for the study and WS, LR, SJ and SP developed the concept. MV, M-HS and AM designed the study. MV obtained the data and MV, M-HS and JL analysed the data. AM, MV, M-HS and JL interpreted the data. WS, $\mathrm{LR}, \mathrm{SJ}, \mathrm{AM}, \mathrm{MH}-\mathrm{HS}$, JL and MV contributed to the data validation. MV, AM and M-HS drafted and finalised the paper. All authors critically reviewed the manuscript, and provided final approval for submission.

\section{Acknowledgements}

The authors would like to express their gratitude to all ATOME country team members for their contribution to the ATOME project.

This paper was prepared on behalf of the ATOME consortium which was composed of ten partners from the fields of palliative care (Department of Palliative Medicine, University of Bonn, Germany; Hospice Casa Sperantei, Brasov, Romania; Help the Hospices, London, UK; International Observatory on End of Life Care, Lancaster University, UK; European Association for Palliative Care, Milan, Italy); law/health policy 
(World Health Organization, Geneva, Switzerland; Utrecht University, Utrecht, The Netherlands); harm reduction (Eurasian Harm reduction Network, Vilnius, Lithuania; National Anti-Drug Agency, Bucharest, Romania; Harm Reduction International, London, UK). Together, this group consisted of national, European-wide and international organisations with long-standing experience in opioid medicine issues; the ten ATOME partners worked with the country teams, including government officials and public health and medicines experts, to carry out legislative and policy reviews, leading to recommendations that aimed to facilitate access for all patients requiring treatment with medicines controlled under international drug conventions.

The Division of Pharmacoepidemiology and Clinical Pharmacology of Utrecht University is designated as a WHO Collaborating Centre for Pharmaceutical and Regulation. The WHO Collaborating Centre for Pharmaceutical Policy \& Regulation receives no direct funding or donations from private parties, including pharma industry. Research funding from public-private partnerships, e.g. IMI, TI Pharma (www.tipharma.nl), is accepted under the condition that no company-specific product or company related study is conducted. The Centre has received unrestricted research funding from public sources, e.g. Netherlands Organisation for Health Research and Development (ZonMW), the Dutch Health Care Insurance Board (ZIN), EU 7th Framework Program (FP7), the Dutch Medicines Evaluation Board (MEB), and the Dutch Ministry of Health, Welfare and Sport.

The research leading to these results has received funding from the European Community's Seventh Framework Programme [FP7/2007-2013] under grant agreement $n^{\circ} 222994$ with the overall aim to improve the access to opioid medication in Europe. Core scientific group / work package leaders: Lukas Radbruch, University of Bonn / Malteser Krankenhaus Bonn/Rhein-Sieg, Germany; Willem Scholten, Consultant Medicines and Controlled Substances, The Netherlands; Sheila Payne, Lancaster University, United Kingdom; Sergey Votyagov, Eurasian Harm Reduction Association, Lithuania; Daniela Mosoiu, Hospice Casa Sperantei, Romania; Paula Frusinoiu, National 
Anti-Drug Agency, Romania; David Praill, Help the Hospices, United Kingdom; Rick Lines, Harm Reduction International, United Kingdom; Marie-Hélène Schutjens, Utrecht University, The Netherlands; Shelia Payne, European Association for Palliative Care, Italy.

Academic Advisory Board: Snezana Bosnjak, Institute for Oncology \& Radiology, Serbia; David Clark, University of Glasgow, UK; Ambros Uchtenhagen, Institut für Sucht- und Gesundheitsforschung Zürich, Switzerland; John Lisman, Lisman Legal Life Sciences, the Netherlands; Stein Kaasa, The Norwegian University of Science and Technology (NTNU), Norway; Per Sjøgren, Rigshospitalet, Copenhagen, Denmark.

Project management: Lukas Radbruch (project coordinator); Saskia Jünger (project executive officer); Willem Scholten (scientific coordinator); Sheila Payne.

\section{References}

1. Caraceni, A. et al. Use of opioid analgesics in the treatment of cancer pain: evidence-based recommendations from the EAPC. Lancet. Oncol. 13, e58-68 (2012).

2. World Health Organization. WHO Model List of Essential Medicines (adults), 19th ed. Geneva (2015). http://www.who.int/medicines/publications/essentialmedicines/en/ (accessed July 8, 2015).

3. Duthey, B. \& Scholten, W. Adequacy of opioid analgesic consumption at country, global, and regional levels in 2010, its relationship with development level, and changes compared with 2006. J. Pain Symptom Manage. 47, 283-97 (2014). 
4. World Health Organization. Ensuring balance in national policies on controlled substances: guidance for availability and accessibility of controlled medicines. Geneva: WHO (2011). http://whqlibdoc.who.int/publications/2011/9789241564175_eng.pdf (accessed July 8,2015$)$.

5. International Narcotics Control Board. Report of the International Narcotic Control Board for 1999, Freedom from Pain and Suffering. United Nations (1999). https://www.incb.org/documents/Publications/AnnualReports/Thematic_chapter s/English/AR_1999_E_Chapter_I.pdf (accessed July 8, 2015).

6. World Health Organization. Access to Controlled Medications Programme, Framework. (WHO/PSM/QSM/2007) 2007. http://www.who.int/medicines/areas/quality_safety/AccessControlledMedicines Progr.Framework.pdf (accessed July 8, 2015).

7. Portenoy, R. K. \& Lesage, P. Management of cancer pain. 353, 1695-1700 (1999).

8. Human Rights Watch. "Please, do not make us suffer any more.": Acces to pain treatment as a human right. New York: Human Rights Watch (2009). https://www.hrw.org/sites/default/files/reports/health0309web_1.pdf (accessed July 8,2015$)$.

9. Cherny, N. I., Cleary, J., Scholten, W., Radbruch, L. \& Torode, J. The Global Opioid Policy Initiative (GOPI) project to evaluate the availability and accessibility of opioids for the management of cancer pain in Africa, Asia, Latin America and the Caribbean, and the Middle East: introduction and methodology. Ann. Oncol. 24, xi7-xi13 (2013).

10. International Narcotics Control Board. Availability of Opiates for Medical Needs: Report of the International Narcotics Control Board for 1995. United Nations ( 1995).

11. World Health Organization. Cancer pain relief and palliative care: report of a WHO expert committee. Geneva (1990).

http://whqlibdoc.who.int/trs/WHO_TRS_804.pdf (accessed July 8, 2015).

12. World Health Organization. Cancer pain relief: with a guide to opioid availability, 2nd ed. Geneva, 1996. http://whqlibdoc.who.int/publications/9241544821.pdf (accessed July 8, 2015.

13. United Nations. Single convention on narcotic drugs, 1961, as amended by the 1972 protocol amending the single convention on narcotic drugs, 1975. In: United 
Nations Treaty Collection, Chapter VI, Narcotic Drugs and Psychotropic Substances. New York: United Nations, 1977.

14. Merino, J. G. Slowing the opioid analgesic overdose epidemic. Bmj 346, f730-f730 (2013).

15. Rosenau, A. M. Guidelines for opioid prescription: the devil is in the details. Ann. Intern. Med. 158, 843-4 (2013).

16. Rutkow, L. et al. Effect of Florida's Prescription Drug Monitoring Program and Pill Mill Laws on Opioid Prescribing and Use. JAMA Intern. Med. 21205, 1-8 (2015).

17. Breivik, H. \& Stubhaug, A. Burden of disease is often aggravated by opioid treatment of chronic pain patients: Etiology and prevention. Pain 155, 2441-3 (2014).

18. Cleary, J. et al. Formulary availability and regulatory barriers to accessibility of opioids for cancer pain in the Middle East: a report from the Global Opioid Policy Initiative (GOPI). Ann. Oncol. 24 Suppl 1, xi51-9 (2013).

19. Cleary, J., Radbruch, L., Torode, J. \& Cherny, N. I. Formulary availability and regulatory barriers to accessibility of opioids for cancer pain in Asia: a report from the Global Opioid Policy Initiative (GOPI). Ann. Oncol. 24 Suppl 1, xi24-32 (2013).

20. Cleary, J. et al. Formulary availability and regulatory barriers to accessibility of opioids for cancer pain in India: a report from the Global Opioid Policy Initiative (GOPI). Ann. Oncol. 24 Suppl 1, xi33-40 (2013).

21. Cleary, J., Radbruch, L., Torode, J. \& Cherny, N. I. Next steps in access and availability of opioids for the treatment of cancer pain: reaching the tipping point? Ann. Oncol. 24 Suppl 1, xi60-4 (2013).

22. International Narcotics Control Board. Report Follow-up to the Twentieth Special Session of the General Assembly. New York: United Nations (2009).

23. Council of Europe. Recommendation Rec (2003) 24 of the Committee of Ministers to Member States on the Organisation of Palliative Care and Explanatory Memorandum. 2003.

24. Vranken, M. J. M. et al. Legal Barriers in Accessing Opioid Medicines: Results of the ATOME Quick Scan of National Legislation of Eastern European Countries. J. Pain Symptom Manage. (2014). doi:10.1016/j.jpainsymman.2014.02.013 
25. Cherny, N. I., Baselga, J., de Conno, F. \& Radbruch, L. Formulary availability and regulatory barriers to accessibility of opioids for cancer pain in Europe: a report from the ESMO/EAPC Opioid Policy Initiative. Ann. Oncol. 21, 615-26 (2010).

26. Joranson, D. E. \& Ryan, K. M. Ensuring opioid availability: methods and resources. J. Pain Symptom Manage. 33, 527-32 (2007).

27. Lima, M. H. A. L. De, Ann, J., Hill, C. S. \& Bruera, E. Legislation analysis according to WHO and INCB criteria on opioid availability : a comparative study of 5 countries and the state of Texas. 56, 99-110 (2001).

28. ATOME legislation review workshop, Utrecht, Netherlands (January 31. (2013). at $<$ Report of the ATOME legislation review workshop. www.atomeproject.eu/documents/atome_legislation_review_workshop.pdf (accessed August 2 2013).

29. Cleary, J. et al. Formulary availability and regulatory barriers to accessibility of opioids for cancer pain in Africa: a report from the Global Opioid Policy Initiative (GOPI). Ann. Oncol. 24 Suppl 1, xi14-23 (2013).

30. Cleary, J. et al. Formulary availability and regulatory barriers to accessibility of opioids for cancer pain in Latin America and the Caribbean: a report from the Global Opioid Policy Initiative (GOPI). Ann. Oncol. 24 Suppl 1, xi41-50 (2013).

31. Mosoiu, D., Ryan, K. M., Joranson, D. E. \& Garthwaite, J. P. Reform of drug control policy for palliative care in Romania. Lancet (London, England) 367, 2110-7 (2006).

32. ATOME. ATOME conference report Estonia, available at: http://www.atomeproject.eu/documents/estonia-confrep.pdf (accessed April 22, 2015).

33. Krakauer, E. L., Wenk, R., Buitrago, R., Jenkins, P. \& Scholten, W. Opioid inaccessibility and its human consequences: reports from the field. J. Pain Palliat. Care Pharmacother. 24, 239-43 (2010).

34. EAPC, Exploring current worst-case stories, available at: http://www.eapcnet.eu/Themes/Policy/PragueCharter/Truestoriesfromtheworld (assecessed August 26, 2015).

35. Section 6(1), EüM (Ministry of Health) Decree 43/2005 (X.15.) on the system for physician's prescriptions, trading in pharmacies, consumption, recording and storage at healthcare providers of medicinal products classified as controlled drugs. 
36. Article 1 (6), Presidential Decree 148/2007 on the codification of the provisions stipulated in the regulatory decrees and ministerial orders regarding national legislation on drugs.

37. Article 13 (3) (Amended, SG, issue 55, dated 2005), ORDINANCE No. 21, DATED OCTOBER 12TH, 2000, ON THE REQUIREMENTS FOR DOCUMENTATION AND REPORTING DURING ACTIVITIES INVOLVING NARCOTIC SUBSTANCES AND THEIR PREPARATIONS.

38. Section 3(4), The Conditions and Procedure for the Issue of Prescriptions for Medicinal Products and for the Dispensing of Medicinal Products by Pharmacies and the Format of Prescriptions (Approved by Regulation No. 30 of the Minister of Social Affairs of 18 February 2005 (RTL 2005, 23, 315), entered into force 01.03.2005.

39. Article 24.1, Order of the Minister of Health of the Republic of Lithuania No. 112 of 8 March 2002 "On Medical Prescriptions and Disbursement (Sale) of Medicines" (Published: Official Gazette Valstybès Žinios, 16/03/2002, No. 28, Publication No. 1013).

40. Article 32, Order of the Minister of Health of the Republic of Lithuania No. 112 of 8 March 2002 "On Medical Prescriptions and Disbursement (Sale) of Medi-cines" (Published: Official Gazette Valstybès Žinios, 16/03/2002, No. 28, Publication No. 1013).

41. Article 38 (2), Rules on classifying, prescribing and dispensing medicinal products for human use.

42. Article 4.9.4, Republic of Lithuania Government Resolution No. 591 of 30 May 2005 "On the Approval of the Description of the Procedure for Monitoring the Use of Narcotic and Psy-chotropic Substances, Consequences thereof, the Circulation of the Precursors of Narcotic and Psychotropic Sub-stances".

43. Article 4.10, Republic of Lithuania Government Resolution No. 591 of 30 May 2005 "On the Approval of the Description of the Procedure for Monitoring the Use of Narcotic and Psy-chotropic Substances, Consequences thereof, the Circulation of the Precursors of Narcotic and Psychotropic Sub-stances".

44. Article 1(1), Act No. 3459/2006 on Legal Codes for Drugs.

45. Article 14, Rulebook on the prescription and dispensing of medicines (FRY Official Gazette No. 16/94, 22/97, 52/02. 
46. Article 68 (2) (amend. and suppl. - SG 22/10), LAW FOR CONTROL OVER THE NARCOTIC SUBSTANCES AND PRECURSORS (1999).

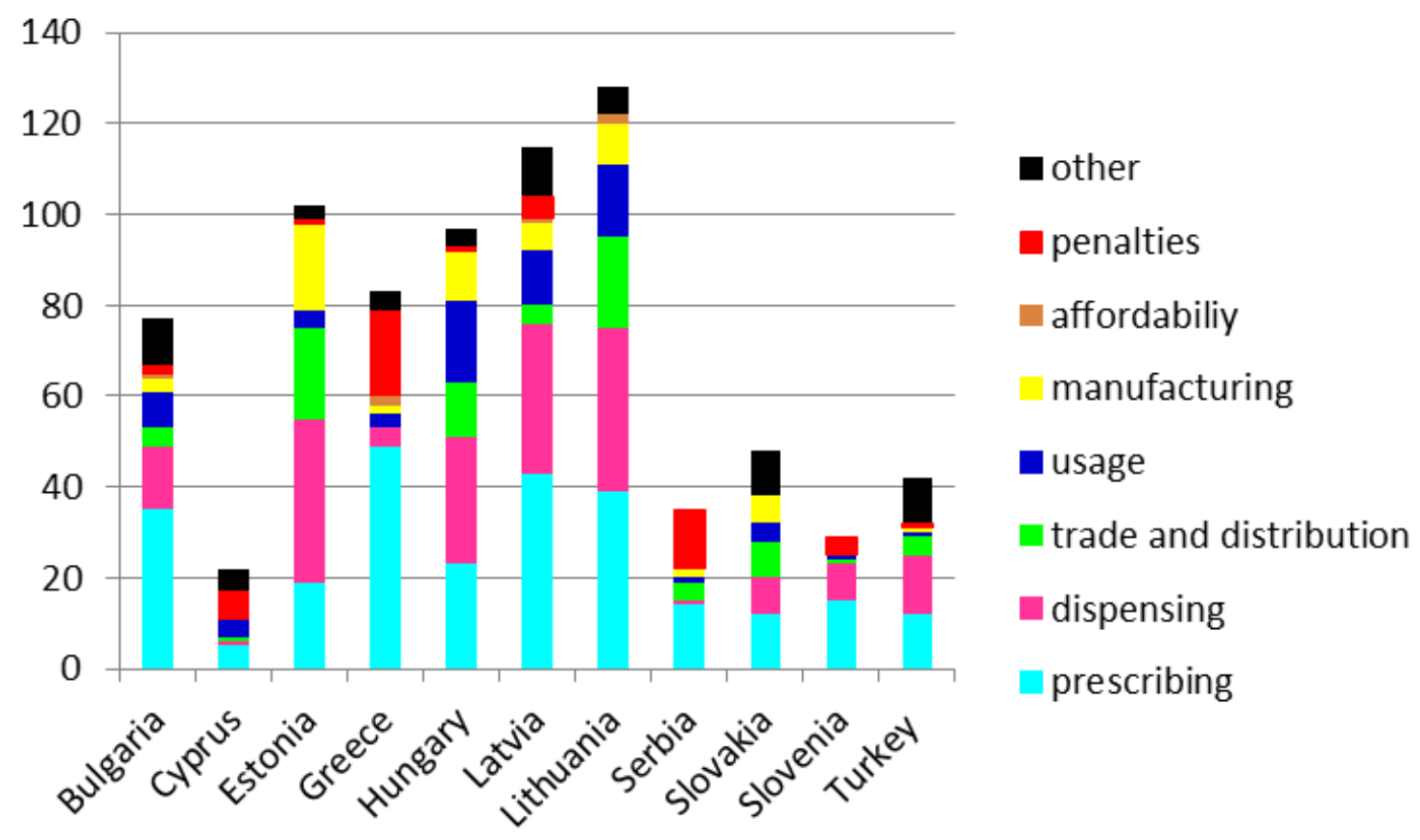


Figure 1: total number of potential barriers identified per country according to category (except category language)

Table 1: assessment instrument examples of potential barriers in the category prescribing and language

\begin{tabular}{|c|c|c|c|}
\hline ITEM & POTENTIAL BARRIER FOR EXAMPLE IF... & $\begin{array}{l}\text { RELATES TO WHO } \\
\text { POLICY GUIDELINE }\end{array}$ & EXAMPLES: POTENTIAL BARRIERS IDENTIFIED IN LEGISLATION \\
\hline $\begin{array}{l}\text { authorisation to prescribe } \\
\text { is restricted }\end{array}$ & $\begin{array}{l}\text {.... the competence to prescribe controlled medicines is } \\
\text { restricted to a limited number of medical specialists } \\
\text { (such as oncologists only) and other appropriately } \\
\text { trained and qualified physicians are not authorised to } \\
\text { prescribe controlled medicines. }\end{array}$ & GUIDELINE 11 & $\begin{array}{l}\text { "If it appears that a patient will need to use a controlled } \\
\text { substance for longer than } 30 \text { days or will need it repeatedly, } \\
\text { the family practitioner only shall be authorized to prescribe it } \\
(\text { (...)." }\end{array}$ \\
\hline $\begin{array}{l}\text { special permit/ license } \\
\text { required for prescribing }\end{array}$ & $\begin{array}{l}\text {...only designated institutions are allowed to prescribe } \\
\text { controlled medicines or if a special permit or license is } \\
\text { required for prescribing controlled medicines, in } \\
\text { particular if the application procedure is complex and if } \\
\text { high fees apply to applicants. }\end{array}$ & GUIDELINE 11 & $\begin{array}{l}\text { “(...) In cases of cancer patients, and only after a relevant } \\
\text { permit by the health department of the local prefectural } \\
\text { administration, the physician can dispense a special narcotics } \\
\text { prescription for an amount that exceeds the maximum daily } \\
\text { dose for a five-day (5) treatment. The local prefectural } \\
\text { administration's permit is valid for one (1) month." }\end{array}$ \\
\hline $\begin{array}{l}\text { special prescription forms } \\
\text { required / prescribing in } \\
\text { multiple copies required }\end{array}$ & $\begin{array}{l}\text {...if special forms or multiple copies are required, in } \\
\text { particular if these special prescription forms are not } \\
\text { readily available and/or are not free of charge and/or } \\
\text { entail many administrative requirements for healthcare } \\
\text { professionals, in particular if unintended violation of } \\
\text { these administrative requirements may result in severe } \\
\text { sanctions. }\end{array}$ & GUIDELINE 9 & $\begin{array}{l}\text { "The persons involved in activities related to narcotic } \\
\text { substances shall purchase the special forms from the regional } \\
\text { healthcares centres." } \\
\text { "The size of the original copy of a prescription for narcotic } \\
\text { drugs is } 127 \times 158 \mathrm{~mm} \text {, three sheets. The pharmacy shall have } \\
\text { the original prescription and one copy thereof and the health } \\
\text { care provider shall have one copy. }{ }^{38}\end{array}$ \\
\hline $\begin{array}{l}\text { limited prescription } \\
\text { validity }\end{array}$ & $\begin{array}{l}\text {...patients in need of controlled medicines - especially } \\
\text { patients with chronic conditions - have to visit the } \\
\text { physician and pharmacy frequently, in particular if } \\
\text { additional rules aggravating the impact apply, such as } \\
\text { rules that limit the total amount of controlled medicine } \\
\text { to be prescribed. }\end{array}$ & GUIDELINE 9 & $\begin{array}{l}\text { "Prescriptions issued by physicians are valid for the following } \\
\text { periods of time: (...) Narcotic drugs - } 5 \text { days, including the day } \\
\text { the prescription was issued; (...)"39 }\end{array}$ \\
\hline amount of controlled & ...patients who require medical treatment with & GUIDELINE 9 & $\begin{array}{l}\text { "If there is no other way to suppress the pain, it shall be } \\
\text { allowed to exceed } 3 \text { times the norms, indicated in the table of }\end{array}$ \\
\hline
\end{tabular}




\begin{tabular}{|c|c|c|c|}
\hline $\begin{array}{l}\text { medicine to be prescribed } \\
\text { is limited }\end{array}$ & $\begin{array}{l}\text { controlled medicines for a longer period have to visit } \\
\text { the physician and pharmacy frequently, in particular if in } \\
\text { addition to this potential barrier the validity of a } \\
\text { medical prescription for controlled medicines is limited. }\end{array}$ & & $\begin{array}{l}\text { paragraph } 31 \text {, indicating in the prescription "Special } \\
\text { assignment" and confirming it additionally by affixing the } \\
\text { physician's signature and personal stamp." }\end{array}$ \\
\hline daily dosage is limited & $\begin{array}{l}\text {...the maximum dosage is lower than evidence based } \\
\text { medical treatment guidelines advice and/or individual } \\
\text { patient needs may require higher dosages. }\end{array}$ & GUIDELINE 11 & $\begin{array}{l}\text { "Per day of treatment, a general practitioner may only } \\
\text { prescribe one tenth of the quantities specified in the previous } \\
\text { paragraph per individual patient, while the total quantity of a } \\
\text { medicinal product prescribed may not exceed the quantity } \\
\text { specified in the previous paragraph." }\end{array}$ \\
\hline $\begin{array}{l}\text { no clear distinction } \\
\text { between medical use and } \\
\text { illicit use/abuse }\end{array}$ & $\begin{array}{l}\text {...the language used in legislation does not provide a } \\
\text { clear distinction between medical use and illicit } \\
\text { use/abuse and as a result causes confusion and/or fear } \\
\text { for the use of opioid medicines in medical practice, in } \\
\text { particular when severe sanctions are involved for } \\
\text { unintended violations. }\end{array}$ & GUIDELINE 10 & $\begin{array}{l}\text { "Preventive measures (...) in order to reduce the supply of } \\
\text { narcotic and psychotropic substances (...)." } \\
\text { "(...) when the use of narcotic and psychotropic substances } \\
\text { was the main reason causing death." }\end{array}$ \\
\hline $\begin{array}{l}\text { incorrect definitions are } \\
\text { used }\end{array}$ & $\begin{array}{l}\text {...the language used contains biased definitions or } \\
\text { presuppositions regarding the nature, effect, or rational } \\
\text { use of opioids that may encourage distorted knowledge } \\
\text { or assumptions and/or may cause fear for the use of } \\
\text { opioid medicines in medical practice, in particular when } \\
\text { severe sanctions are involved for unintended violations. }\end{array}$ & GUIDELINE 10 & $\begin{array}{l}\text { "According to their legal definition, narcotic drugs are artificial } \\
\text { or natural substances that act on the central nervous system } \\
\text { and cause the individual in question to develop an addiction to } \\
\text { them." }\end{array}$ \\
\hline unclear language is used & $\begin{array}{l}\text {...the language used contains wording and/or } \\
\text { terminology that leave space for interpretation (for } \\
\text { example, the use of vague adjectives) and cause } \\
\text { confusion and/or cause fear for the use of opioid } \\
\text { medicines in medical practice, in particular when severe } \\
\text { sanctions are involved for unintended violations. }\end{array}$ & GUIDELINE 10 & $\begin{array}{l}\text { "Medicines containing narcotic drugs can be prescribed only if } \\
\text { their use is necessary and if they are marketed under the Law } \\
\text { on production and marketing of medicines." }\end{array}$ \\
\hline $\begin{array}{l}\text { controlled medicines are } \\
\text { referred to as dangerous, } \\
\text { toxic or addictive drugs }\end{array}$ & $\begin{array}{l}\text {...the language used contributes to the stigmatisation of } \\
\text { opioid medicines and/or causes fear for the use of } \\
\text { opioid medicines in medical practice. }\end{array}$ & GUIDELINE 10 & $\begin{array}{l}\text { "For medical products, containing intoxicating substances, the } \\
\text { packing must be marked diagonally by two red strips (...)." }\end{array}$ \\
\hline
\end{tabular}


Table 2: assessment instrument showing potential barriers identified in eight categories (all except language) according to item (subcategory) per country

\begin{tabular}{|c|c|c|c|c|c|c|c|c|c|c|c|c|}
\hline 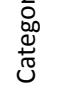 & IITEM & BULGARIA & CYPRUS & ESTONIA & GREECE & HUNGARY & LATVIA & LITHUANIA & SERBIA & SLOVAKIA & SLOVENIA & TURKEY \\
\hline \multirow{7}{*}{ 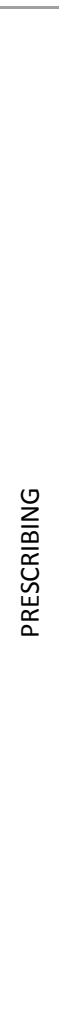 } & $\begin{array}{l}\text { authorisation to prescribe is } \\
\text { restricted }\end{array}$ & & & & & & & & & & & \\
\hline & $\begin{array}{l}\text { permit//icense required for } \\
\text { prescribing }\end{array}$ & & & & & & & & & & & \\
\hline & $\begin{array}{l}\text { special prescription forms } \\
\text { required }\end{array}$ & & & & & & & & & & & \\
\hline & multiple copies required & & & & & & & & & & & \\
\hline & limited prescription validity & & & & & & & & & & & \\
\hline & $\begin{array}{l}\text { amount of controlled } \\
\text { medicine to be prescribed is } \\
\text { limited }\end{array}$ & & & & & & & & & & & \\
\hline & daily dosage is limited & & & & & & & & & & & \\
\hline
\end{tabular}




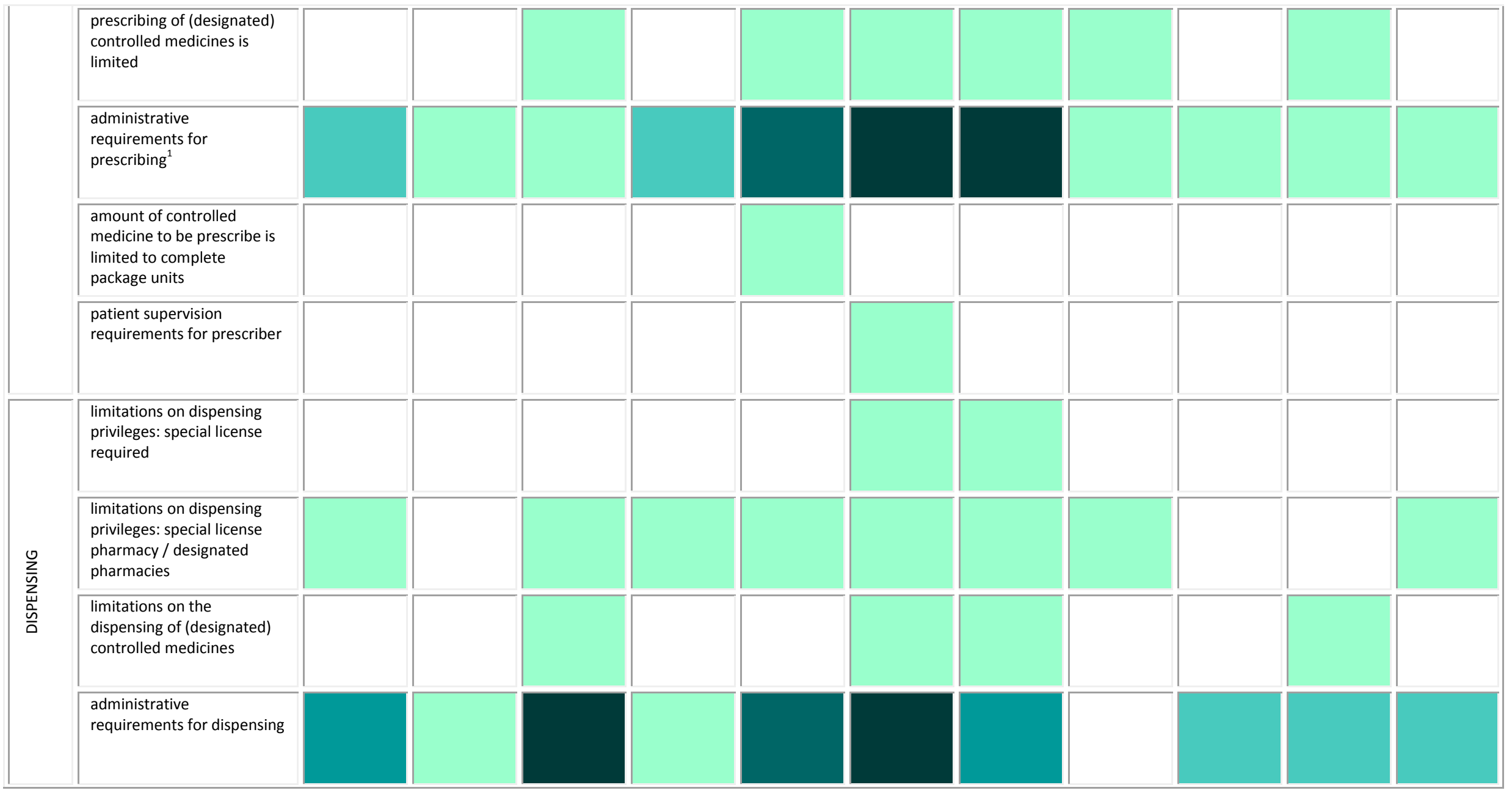

${ }^{1}$ Requirements that increase the administrative burden and may cause medical practitioners to be unable or reluctant to treat patients with controlled medicines and do not solely concern any of the other categories. For example, the requirement that physicians are allowed to receive a limited number of prescription forms which need to be stored in a designated safe. 


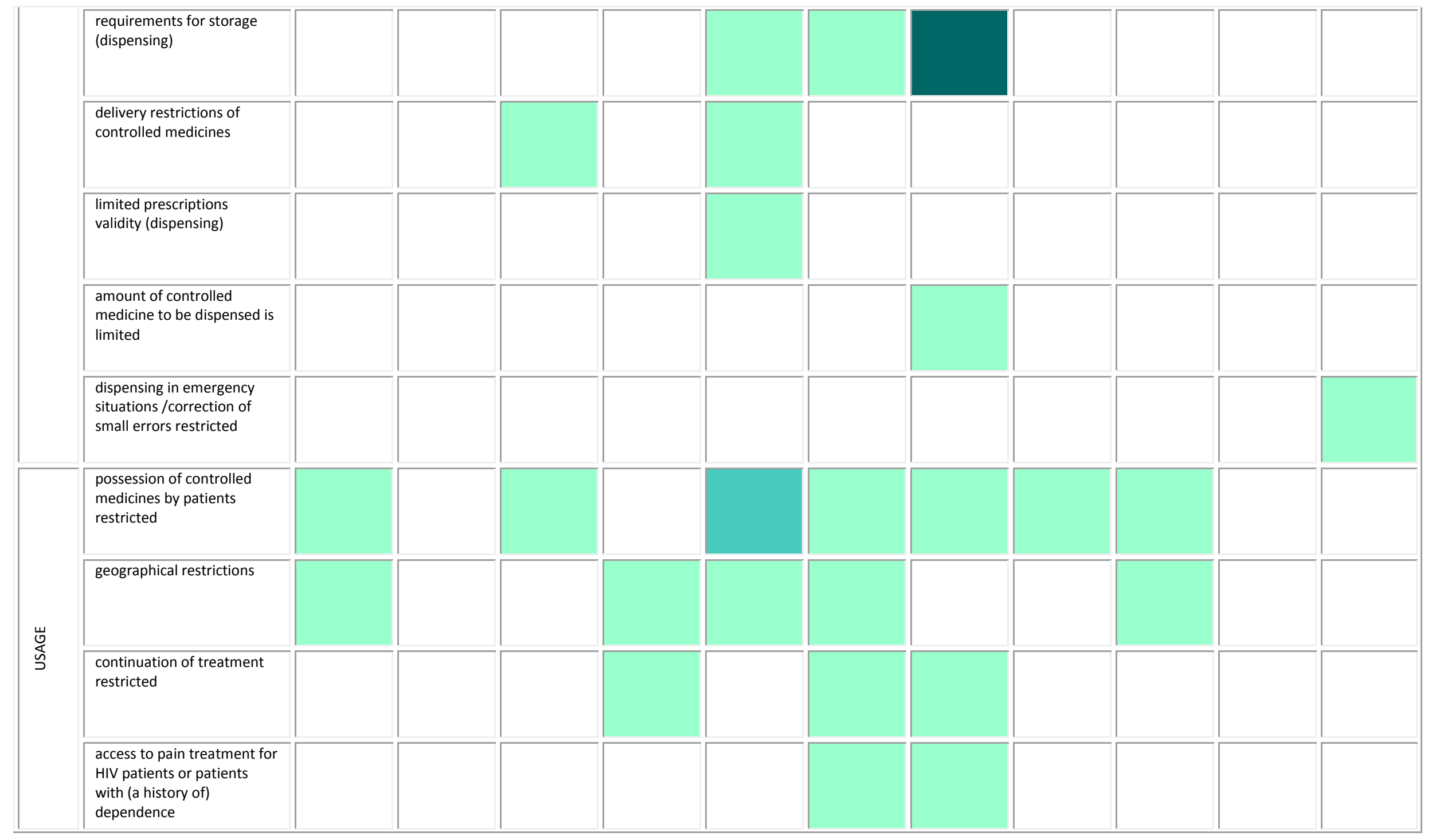




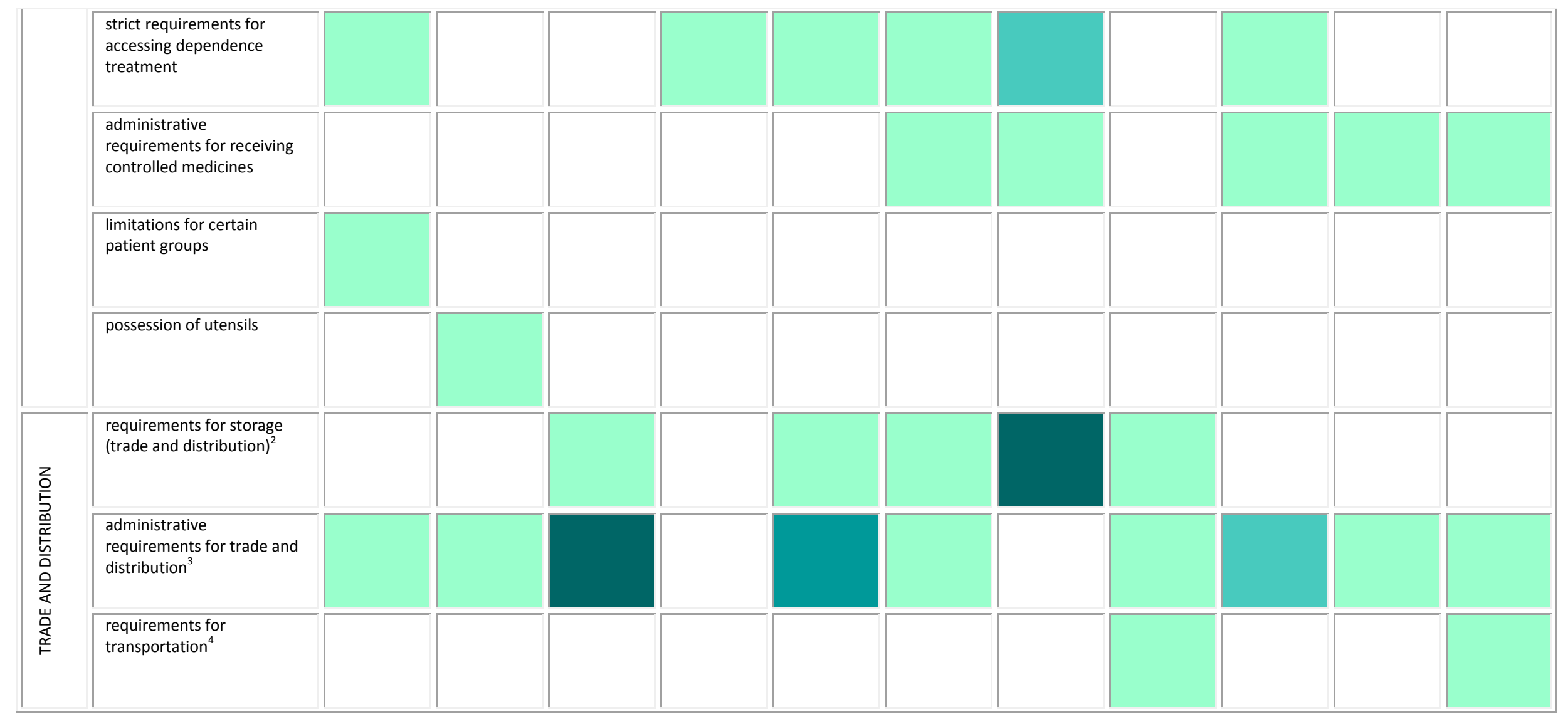

\footnotetext{
${ }^{2}$ Requirements that may cause legal entities to be unable or reluctant to store controlled medicines due to the high costs of the security measures. For example, requirements regarding the safes, security systems or requirements that dictate the thickness of the bars in the windows.

3 Requirements that increase the administrative burden and may cause legal entities to be unable or reluctant to trade in controlled medicines. For example, very strict timelines for completing the application for an import or export license, in particular if the information requested cannot be easily retrieved.

4 Requirements that may cause legal entities to be unable or reluctant to transport controlled medicines due to the high costs of these security measures. For example, the requirement that controlled medicines can only be transported in a vehicle that is equipped with metal containers with special security locks.
} 


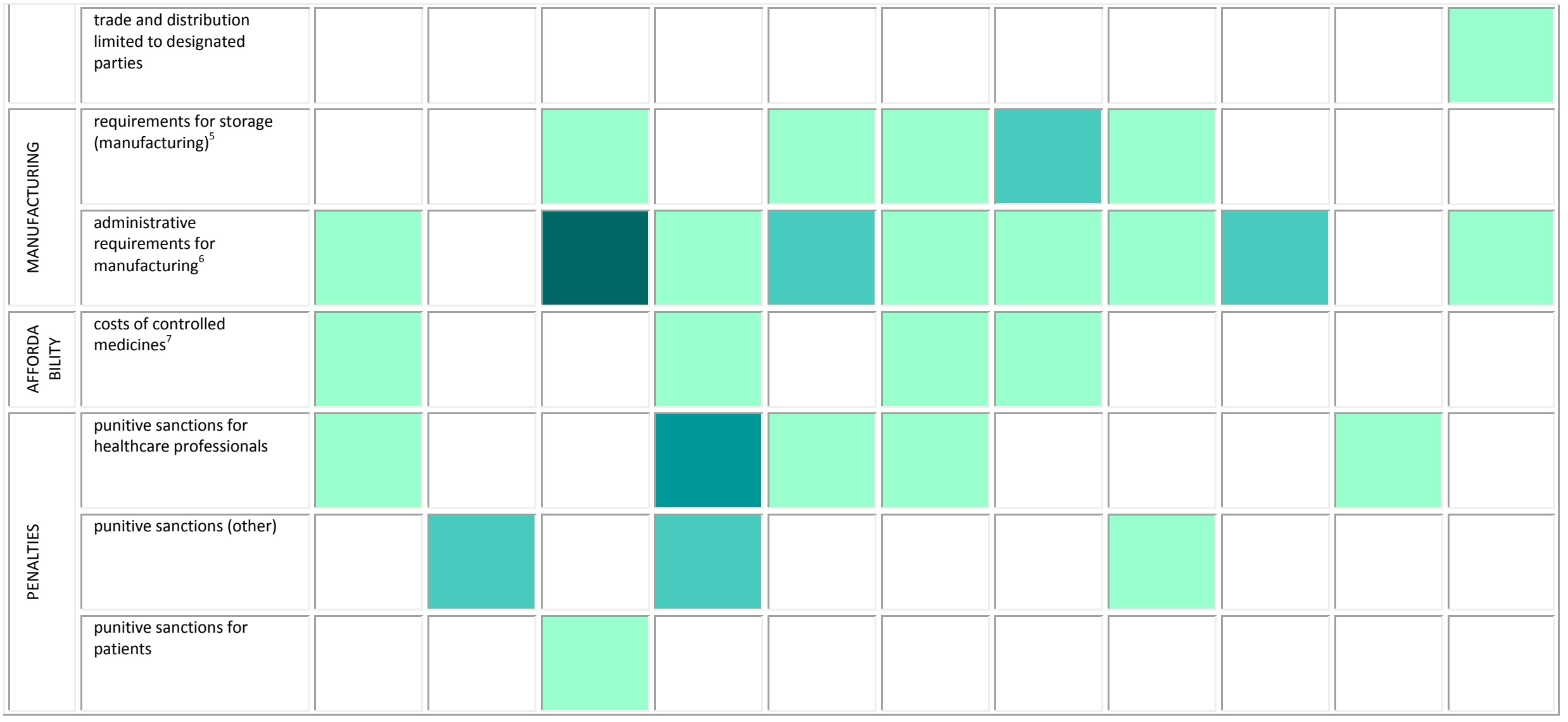

\footnotetext{
${ }^{5}$ Requirements that may cause legal entities involved in manufacturing to be unable or reluctant to store controlled medicines due to the high costs of the security measures. For example, requirements regarding the safes, security systems or requirements that dictate the thickness of the bars in the windows.

6 Requirements that increase the administrative burden and may cause legal entities to be unable or reluctant to manufacture controlled medicines. For example, very strict timelines for completing the application to receive a permit for manufacturing opioid medicines, in particular if the information requested cannot be easily retrieved.

7 For example, costs are not reimbursed by statutory funding schemes; high prices/taxes due to state monopoly; high monthly fee for patients to be able to receive dependence treatment.
} 


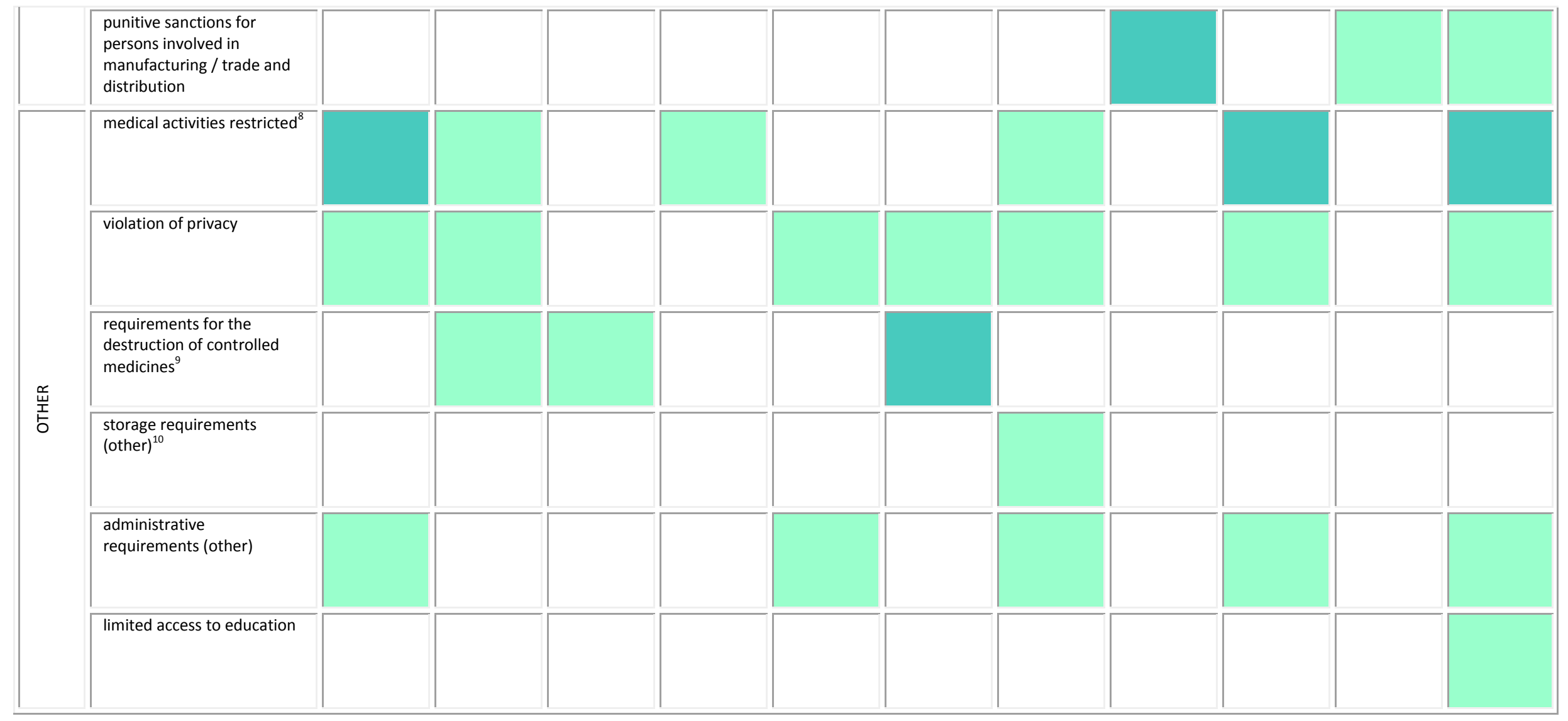

8 Restrictions that have an impact on medical activities and do not solely concern any of the other categories. For example, specific requirements for healthcare institutions providing treatment with controlled medicines.

9 Requirements for the destruction of controlled medicines that may deter legal entities or healthcare professionals from working with controlled medicines. For example, complex reporting requirements for the disposal of controlled medicines or the requirement that unusable controlled medicines can only be destroyed in the presence of a representative from the government.

10 Storage requirements that do not fit any of the other categories. For example, storage of opioid medicines during international transportation. 


\begin{tabular}{|c|c|c|c|c|c|}
\hline $\begin{array}{c}\text { NO POTENTIAL } \\
\text { BARRIERS IDENTIFIED }\end{array}$ & $\begin{array}{c}\text { 1-5 POTENTIAL } \\
\text { BARRIERS IDENTIFIED }\end{array}$ & $\begin{array}{c}\text { 6-10 POTENTIAL } \\
\text { BARRIERS IDENTIFIED }\end{array}$ & $\begin{array}{l}\text { 11-15 POTENTIAL } \\
\text { BARRIERS IDENTIFIED }\end{array}$ & $\begin{array}{c}\text { 16-20 POTENTIAL } \\
\text { BARRIERS IDENTIFIED }\end{array}$ & $\begin{array}{c}\geq 21 \text { POTENTIAL } \\
\text { BARRIERS IDENTIFIED }\end{array}$ \\
\hline
\end{tabular}

Table 3: Individual differences in the level of impediment of potential barriers (category prescribing)

\begin{tabular}{|c|c|c|c|c|}
\hline country & limited prescription validity & $\begin{array}{l}\text { multiple copies or special } \\
\text { forms required }\end{array}$ & $\begin{array}{l}\text { total amount or treatment } \\
\text { period limited }\end{array}$ & maximum daily dosage \\
\hline Bulgaria & $\begin{array}{l}7 \text { days from the date of } \\
\text { issuance }\end{array}$ & $\begin{array}{l}\text { three copies: original and two } \\
\text { copies in different colours (yellow } \\
\text { and green) printed on carbon paper }\end{array}$ & 30 days & not identified \\
\hline Cyprus & 13 weeks & not identified & 13 weeks & not identified \\
\hline Estonia & $\begin{array}{l}30 \text { days (non-controlled } \\
\text { medicines } 60 \text { days) }\end{array}$ & $\begin{array}{l}\text { three copies, } 127 \times 158 \mathrm{~mm} \text { sheets } \\
\text { printed in green on red self-copying } \\
\text { paper with } 80 \mathrm{~mm} \text { binding holes on } \\
\text { the left, a security print on the } \\
\text { margins and a 7-digit number in } \\
\text { black in the upper left-hand corner }\end{array}$ & 30 days & not identified \\
\hline Greece & not identified & $\begin{array}{l}\text { two copies, serial numbered } \\
\text { containing a double red line on the } \\
\text { top right side and the text 'special } \\
\text { narcotic drug prescription' }\end{array}$ & $\begin{array}{l}\text { the amount to be dispensed on a single } \\
\text { prescription varies: } 1 \text { day (substances listed } \\
\text { in Tables B \& C); } 5 \text { days } \\
\text { (dextropropoxyphene, methyphenidate, } \\
\text { pentazocine); } 15 \text { days (fentanyl } \\
\text { transdermal patches); } 30 \text { days (treatment } \\
\text { of patients with cancer, provide that a } \\
\text { permit is granted: permit valid } 1 \text { month). }\end{array}$ & $\begin{array}{l}\text { maximum daily dosages in } \\
\text { legislation, e.g. morphine } 50 \\
\text { mg; maximum daily dosages } \\
\text { can be exceeded for the } \\
\text { treatment of patients with } \\
\text { cancer, during maximum } 5 \\
\text { days, provided that a permit is } \\
\text { granted }\end{array}$ \\
\hline Hungary & 5 days & not identified & $\begin{array}{l}15 \text { days / } 30 \text { days (prescribed by general } \\
\text { practitioner) / } 90 \text { days (prescribed by } \\
\text { general practitioner for patients travelling); } \\
\text { repeat prescription allowed by general } \\
\text { practitioner for max } 30 \text { days }\end{array}$ & not identified \\
\hline
\end{tabular}




\begin{tabular}{|c|c|c|c|c|}
\hline Latvia & $\begin{array}{l}30 \text { days (non-controlled } \\
\text { medicines } 90 \text { days) }\end{array}$ & $\begin{array}{l}\text { margins and part to be completed } \\
\text { by the pharmacy is coloured in light } \\
\text { red }\end{array}$ & $\begin{array}{l}\text { maximum amounts to be prescribed in } \\
\text { Annex } 5 \text { of Regulation No175; treatment } \\
\text { period limited to } 14 \text { days (buprenorphine) / } \\
30 \text { days / } 90 \text { days (only narcotic analgesic } \\
\text { products prescribed by a psychiatrist, } \\
\text { narcologist, neurologist or family doctor) }\end{array}$ & $\begin{array}{l}\text { daily dosage of buprenorphine } \\
\text { legally restricted. }\end{array}$ \\
\hline Lithuania & $\begin{array}{l}5 \text { days, including the day of } \\
\text { issuance. }\end{array}$ & $\begin{array}{l}\text { blank form } 2 \text { for 'narcotic } \\
\text { medicines' and blank form } 3 \text { for } \\
\text { compensated 'narcotic medicines' }\end{array}$ & $\begin{array}{l}\text { maximum amounts to be prescribed for a } \\
\text { patient on a single occasion, e.g. morphine } \\
2 \text { g. total amount limited to a } 7 \text { day } \\
\text { treatment course; transdermal: } 30 \text { days }\end{array}$ & not identified \\
\hline Serbia & $\begin{array}{l}7 \text { days from the date of } \\
\text { issuance }\end{array}$ & $\begin{array}{l}\text { two copies, serial numbered, with } \\
\text { the second copy marked 'copy'. }\end{array}$ & $\begin{array}{l}\text { maximum amounts to be prescribed for a } \\
\text { patient on a single occasion, e.g. } 0.2 \mathrm{~g} \\
\text { morphine; amount limited to treatment } \\
\text { period of } 30 \text { days; for the treatment of } \\
\text { malignant diseases: duration of treatment } \\
\text { limited to } 14 \text { days }\end{array}$ & not identified \\
\hline Slovakia & 5 days & $\begin{array}{l}\text { three copies, forms marked with } \\
\text { blue diagonal stripe }\end{array}$ & 30 days; no repeat prescriptions allowed. & not identified \\
\hline Slovenia & $\begin{array}{l}5 \text { days, excluding the day of } \\
\text { issuance }\end{array}$ & $\begin{array}{l}\text { two copies, serial numbered, with } \\
\text { the second copy marked 'copy'. }\end{array}$ & $\begin{array}{l}30 \text { days; no repeat prescriptions allowed; } \\
\text { maximum amounts to be prescribed } \\
\text { specified in legislation }\end{array}$ & $\begin{array}{l}\text { daily dosage may not exceed } \\
1 / 10 \text { of maximum amounts } \\
\text { specified }\end{array}$ \\
\hline Turkey & not identified & $\begin{array}{l}\text { three copies, serial numbered, } \\
\text { carbon paper in green } \\
\text { (psychotropic substances) or red } \\
\text { (narcotic substances) }\end{array}$ & $\begin{array}{l}\text { maximum amounts to be prescribed on a } \\
\text { single prescription specified in legislation, } \\
\text { e.g. morphine (oral) } 2700 \mathrm{mg}\end{array}$ & not identified \\
\hline
\end{tabular}


Table 4: Potential barriers identified in the category 'language' in legislation

\begin{tabular}{|c|c|c|c|c|c|c|c|c|c|c|c|}
\hline IITEM/COUNTRY & BULGARIA & CYPRUS & ESTONIA & GREECE & HUNGARY & LATVIA & LITHUANIA & SERBIA & SLOVAKIA & SLOVENIA & TURKEY \\
\hline $\begin{array}{l}\text { reference to (persons } \\
\text { with) dependence in a } \\
\text { disrespectful manner in } \\
\text { legislation (e.g. addicts or } \\
\text { addiction) }\end{array}$ & & & & & & & & & & & \\
\hline $\begin{array}{l}\text { incorrect definitions } \\
\text { and/or unclear language } \\
\text { in legislation }\end{array}$ & & & & & & & & & & & \\
\hline $\begin{array}{l}\text { absence of a clear } \\
\text { distinction between } \\
\text { medical use and illicit use } \\
\text { or abuse in legislation }\end{array}$ & & & & & & & & & & & \\
\hline $\begin{array}{l}\text { reference to controlled } \\
\text { medicines as dangerous, } \\
\text { toxic or addictive drugs in } \\
\text { legislation }\end{array}$ & & & & & & & & & & & \\
\hline
\end{tabular}


Annex 1: legal and regulatory documents (partly) translated (printed in bold) and (partly) analysed per country

\begin{tabular}{|c|c|c|c|c|c|}
\hline $\begin{array}{l}\text { Document } \\
\text { s (partly) } \\
\text { analysed }\end{array}$ & $\begin{array}{l}\text { controlled substances legislation } \\
\text { (general) }\end{array}$ & medicinal products legislation & legislation concerning healthcare & $\begin{array}{l}\text { controlled substances legislation } \\
\text { (dependence) }\end{array}$ & other \\
\hline & $\begin{array}{l}\text { Law for Control over the Narcotic } \\
\text { Substances and Precursors (1999) }\end{array}$ & $\begin{array}{l}\text { Law on the Medicinal Products in } \\
\text { Human Medicine (2007) }\end{array}$ & $\begin{array}{l}\text { Ordinance No. } 34 / 2005 \text { on the } \\
\text { procedure for state budget } \\
\text { funding of the treatment of } \\
\text { Bulgarian citizens with regard to } \\
\text { diseases beyond the scope of } \\
\text { compulsory health insurance }\end{array}$ & $\begin{array}{l}\text { Ordinance No. } 24 / 2000 \text { on the } \\
\text { rules and procedures for the } \\
\text { implementation of substitution } \\
\text { and maintenance programs for } \\
\text { the reduction of health damage } \\
\text { for persons addicted to narcotic } \\
\text { drugs }\end{array}$ & \\
\hline 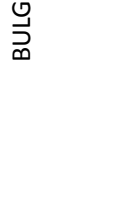 & $\begin{array}{l}\text { Ordinance No. } 21 / 2000 \text { on the } \\
\text { requirements for documentation } \\
\text { and reporting during activities } \\
\text { involving narcotic substances and } \\
\text { their preparations }\end{array}$ & $\begin{array}{l}\text { Ordinance No } 4 / 2009 \text { on the } \\
\text { rules and procedures for the } \\
\text { prescription and supply of } \\
\text { medicinal products }\end{array}$ & & & \\
\hline \multirow{3}{*}{ 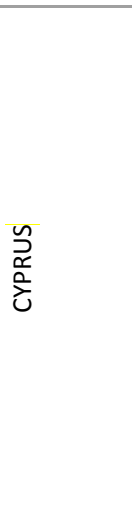 } & $\begin{array}{l}\text { The Narcotic Drugs and } \\
\text { Psychotropic Substances Law } \\
\text { 1977, incorporating amendments } \\
\text { up to } 1992 .\end{array}$ & & & & \\
\hline & $\begin{array}{l}\text { The Narcotic Drugs and } \\
\text { Psychotropic Substances } \\
\text { Regulations 1979, incorporating } \\
\text { amendments up to } 1987 .\end{array}$ & & & & \\
\hline & $\begin{array}{l}\text { The Narcotic Drugs and } \\
\text { Psychotropic Substances } \\
\text { (Amendment) Regulations of }\end{array}$ & & & & \\
\hline
\end{tabular}




\begin{tabular}{|c|c|c|c|c|}
\hline & 1995 (P.I.79/95) & & & \\
\hline & $\begin{array}{l}\text { The Narcotic Drugs and } \\
\text { Psychotropic Substances } \\
\text { (Amendment) Law 91(I) of } 2003\end{array}$ & & & \\
\hline & $\begin{array}{l}\text { The Narcotic Drugs and } \\
\text { Psychotropic Substances } \\
\text { (Amendment) Decree of } 1996 \\
\text { (P.I. 4/96) }\end{array}$ & & & \\
\hline & $\begin{array}{l}\text { The Narcotic Drugs and } \\
\text { Psychotropic Substances } \\
\text { (Amendment) Law 24(I) of } 2010\end{array}$ & & & \\
\hline $\begin{array}{l}\frac{5}{2} \\
0 \\
\frac{0}{4}\end{array}$ & $\begin{array}{l}\text { Act on Narcotic Drugs and } \\
\text { Psychotropic Substances and } \\
\text { Precursors thereof (passed } 11 \\
\text { June 1997, RT I 1997, 52, 834, } \\
\text { entered into force } 1 \text { November } \\
\text { 1997) }\end{array}$ & $\begin{array}{l}\text { Medicinal Products Act } \\
\text { (Passed } 16 \text { December } 2004 \text { (RT I } \\
\text { 2005, 2, 4)Entry into force } 1 \\
\text { March 2005) }\end{array}$ & Health Insurance Act & $\begin{array}{l}\text { The Conditions and Procedure } \\
\text { for the Import and Export, } \\
\text { Carrying for Personal Use and } \\
\text { Sending by Post of Goods } \\
\text { Requiring Special Authorisation } \\
\text { of the State Agency of } \\
\text { Medicines, the Forms of Special } \\
\text { Authorisations and the List of } \\
\text { Goods Requiring Special } \\
\text { Authorisation of the State } \\
\text { Agency of Medicines } \\
\text { (Passed with Regulation No. } 31 \\
\text { on 18.02.2005, RTL 2005, 23, } \\
\text { 316, Entered into force } \\
\text { 01.03.2005) }\end{array}$ \\
\hline
\end{tabular}




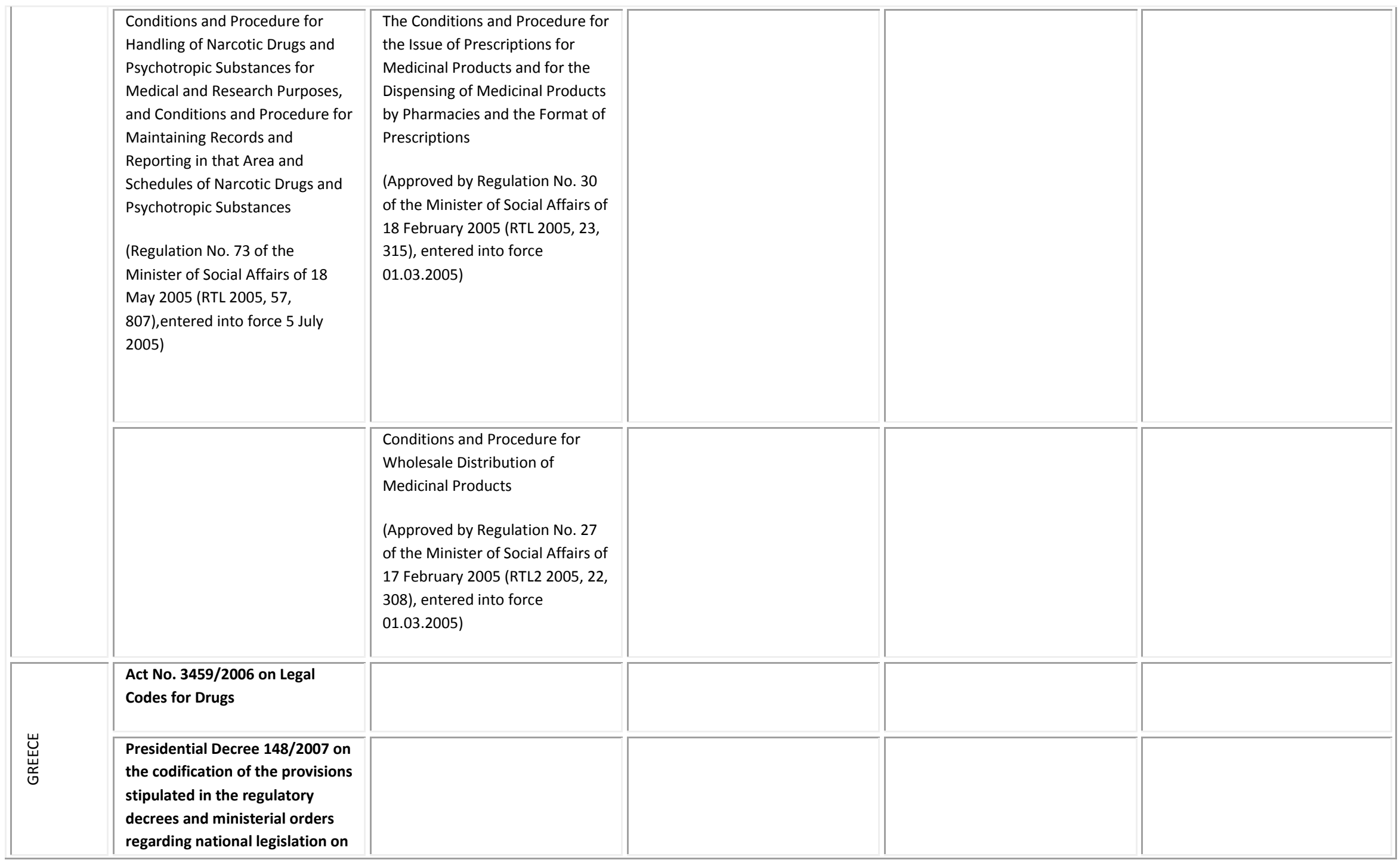




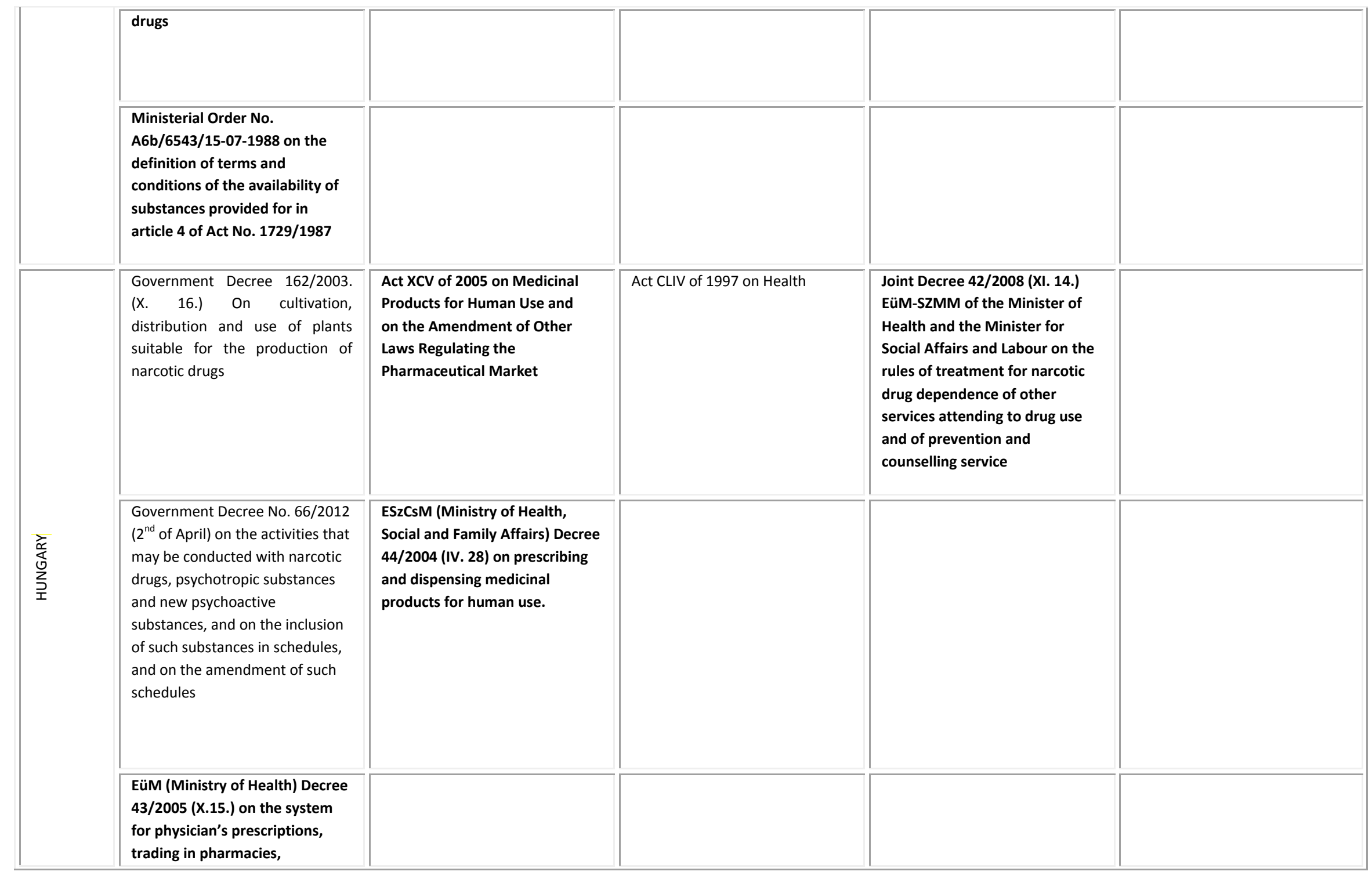




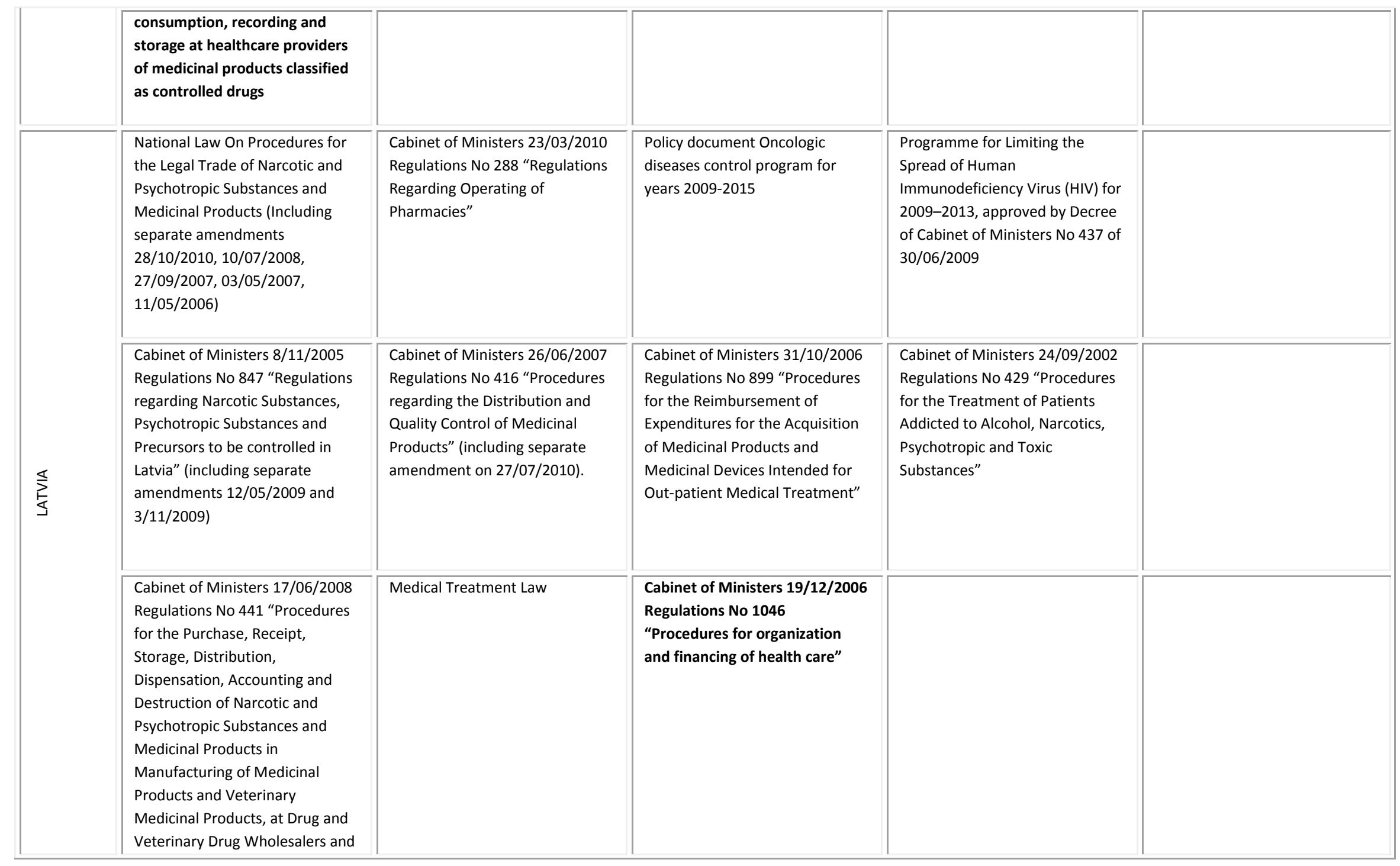




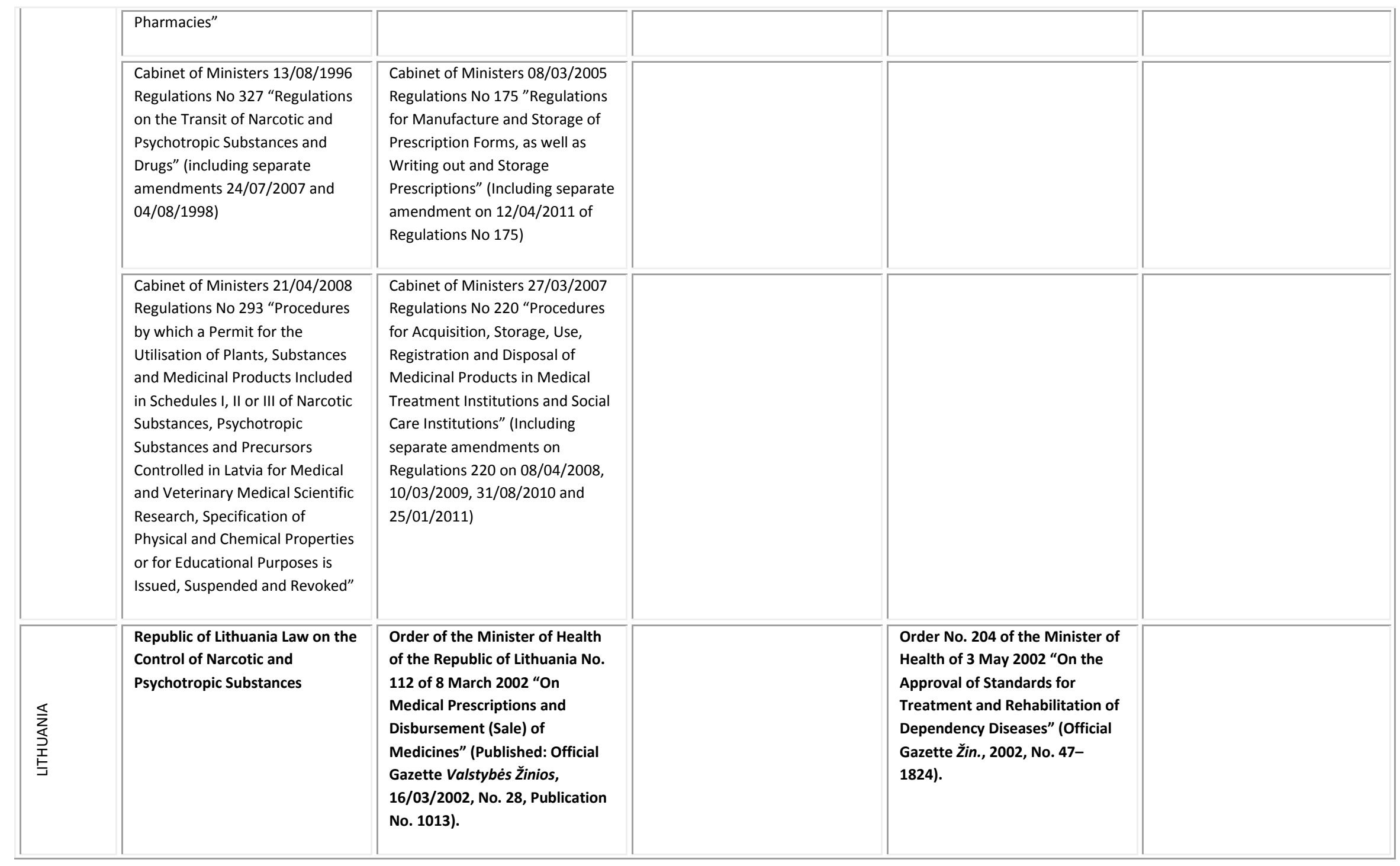




\begin{tabular}{|c|c|}
\hline $\begin{array}{l}\text { Republic of Lithuania Law on the } \\
\text { Control of Precursors of Narcotic } \\
\text { Drugs and Psychotropic } \\
\text { Substances }\end{array}$ & $\begin{array}{l}\text { Order No. V-653 of the Minister } \\
\text { of Health of the Republic of } \\
\text { Lithuania of } 6 \text { August } 2007 \text { "On } \\
\text { the Approval of Procedure } \\
\text { Descriptions for Assigning } \\
\text { Substitution Treatment and its } \\
\text { Application to Treat Opiate } \\
\text { Dependency, and Prescription, } \\
\text { Disbursement, Storage and } \\
\text { Accounting of Substitution } \\
\text { Opiate Medicinal Preparations in } \\
\text { Personal Health Care } \\
\text { Institutions" }\end{array}$ \\
\hline $\begin{array}{l}\text { Government of the Republic of } \\
\text { Lithuanian Resolution regarding } \\
\text { the approval of regulations of } \\
\text { issuing licenses to produce, } \\
\text { import and export narcotic and } \\
\text { psychotropic substances, and to } \\
\text { engage in their wholesale and } \\
\text { retail trade (Last amended on } \\
2011 \text { July 22: No. 887, } \\
\text { 13.07.2011, Zin. (Official } \\
\text { Gazette), 2011, No. 93-4403 } \\
\text { (21.07.2011)) }\end{array}$ & \\
\hline $\begin{array}{l}\text { Republic of Lithuania } \\
\text { Government Resolution No. } 591 \\
\text { of } 30 \text { May } 2005 \text { "On the } \\
\text { Approval of the Description of } \\
\text { the Procedure for Monitoring } \\
\text { the Use of Narcotic and } \\
\text { Psychotropic Substances, } \\
\text { Consequences thereof, the } \\
\text { Circulation of the Precursors of } \\
\text { Narcotic and Psychotropic }\end{array}$ & \\
\hline
\end{tabular}




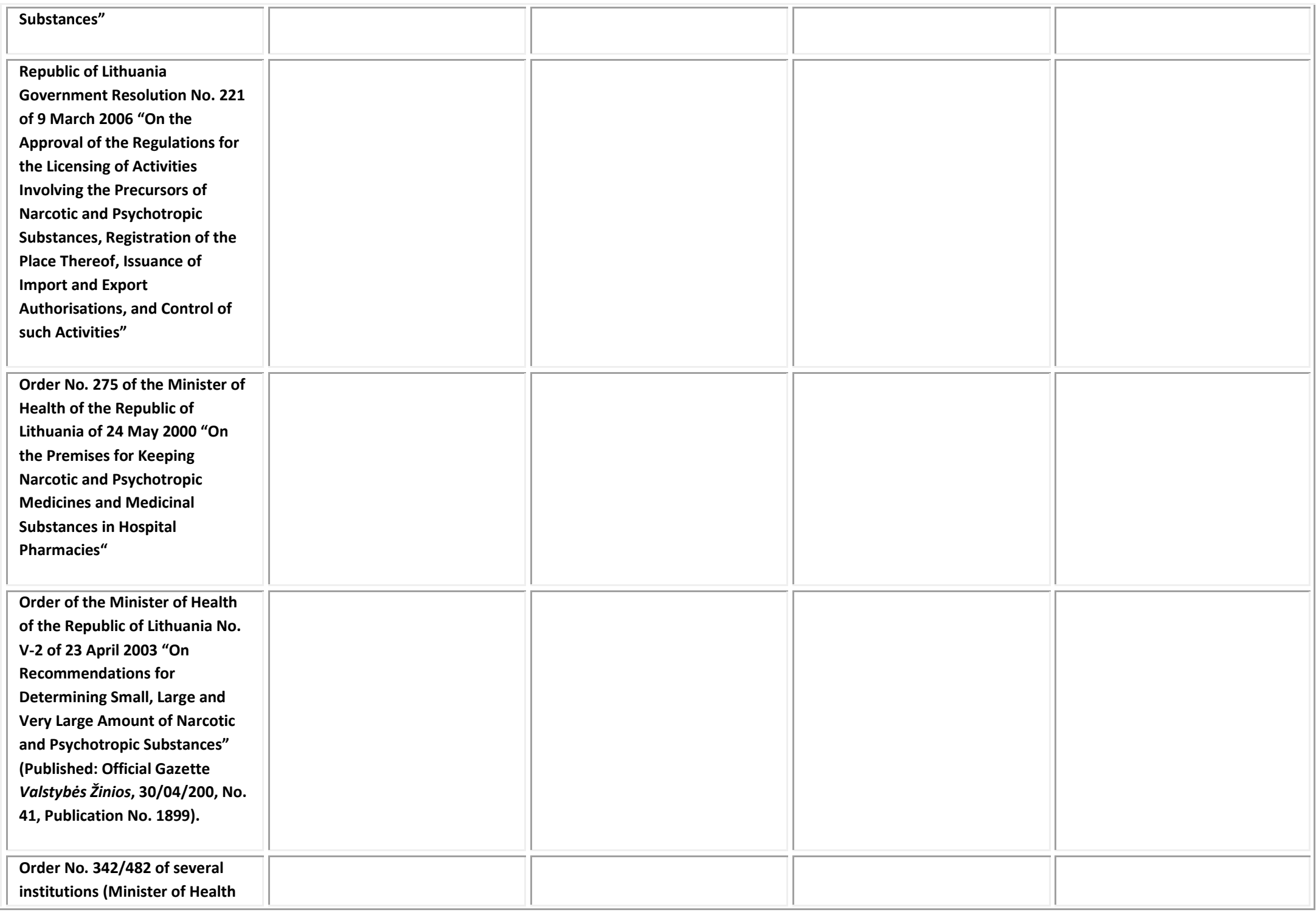




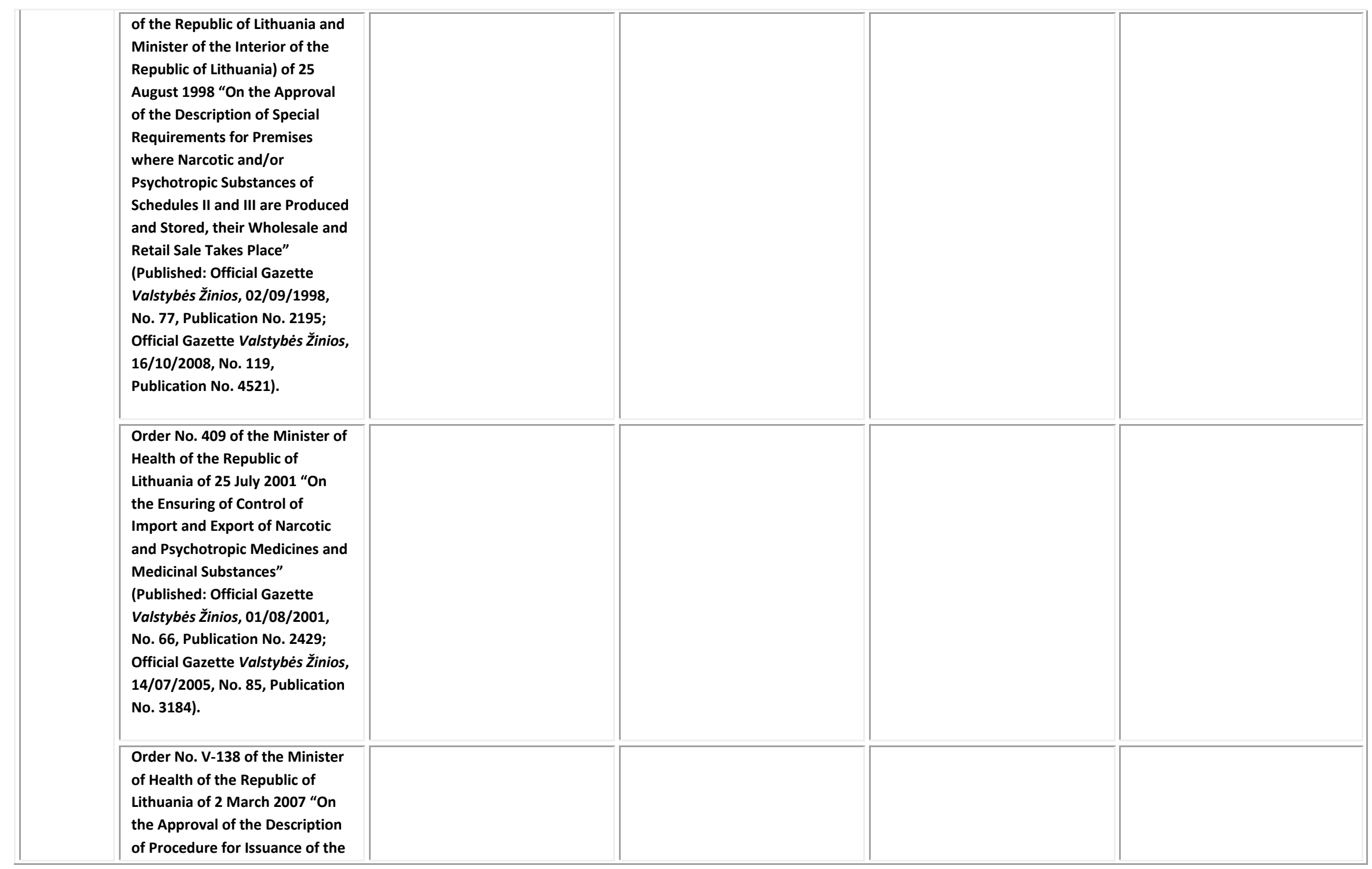




\begin{tabular}{|c|c|c|c|c|}
\hline & $\begin{array}{l}\text { Certificate for Transportation of } \\
\text { Narcotic and/or Psychotropic } \\
\text { Substances for Personal Usage } \\
\text { for Medical Purposes" } \\
\text { (Published: Official Gazette } \\
\text { Valstybès Žinios, 10/03/2007, } \\
\text { No. 30, Publication No. 1109). }\end{array}$ & & & \\
\hline & $\begin{array}{l}\text { Order No. } 294 \text { of the Minister of } \\
\text { Health of the Republic of } \\
\text { Lithuania of } 4 \text { June } 1998 \text { "On the } \\
\text { Procedure of Keeping Narcotic } \\
\text { and Psychotropic Medicines and } \\
\text { Medicinal Substances in Means } \\
\text { of International Transportation" } \\
\text { (Published: Official Gazette } \\
\text { Valstybés Žinios, 19/06/1998, } \\
\text { No. 56, Publication No. 1568). }\end{array}$ & & & \\
\hline \multirow{2}{*}{ 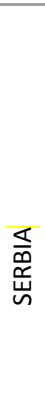 } & $\begin{array}{l}\text { Law on psychoactive controlled } \\
\text { substances }\end{array}$ & $\begin{array}{l}\text { Rulebook on the prescription } \\
\text { and dispensing of medicines } \\
\text { (FRY Official Gazette No. 16/94, } \\
22 / 97,52 / 02 \text { ) }\end{array}$ & $\begin{array}{l}\text { Rulebook on contents and scope } \\
\text { of health care from compulsory } \\
\text { health insurance and on } \\
\text { participation for } 2012\end{array}$ & The criminal code \\
\hline & & $\begin{array}{l}\text { Rulebook on advertising of } \\
\text { medicines and medical devices }\end{array}$ & $\begin{array}{l}\text { Draft National Palliative Care } \\
\text { Strategy }\end{array}$ & Law on criminal procedures \\
\hline
\end{tabular}




\begin{tabular}{|c|c|c|c|c|c|}
\hline & & $\begin{array}{l}\text { Law on medicines and medical } \\
\text { devices (Official Gazette no } \\
\text { 30/10) }\end{array}$ & $\begin{array}{l}\text { Action Plan for Palliative Care in } \\
\text { the Republic of Serbia for the } \\
\text { Period 2008-2015 }\end{array}$ & & \\
\hline \multirow[b]{2}{*}{ 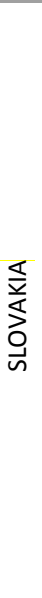 } & $\begin{array}{l}\text { Act. N. 139/1998 on Narcotic } \\
\text { Drugs, Psychotropic Substances } \\
\text { and Preparations }\end{array}$ & $\begin{array}{l}\text { Act. } N .140 / 1998 \text { on medicinal } \\
\text { products and medical devices, } \\
\text { replaced by Act. N. } 362 / 2011 \text { on } \\
\text { medicinal products and medical } \\
\text { devices }^{11}\end{array}$ & $\begin{array}{l}\text { Regulation regarding standards } \\
\text { for diagnosis and treatment }\end{array}$ & $\begin{array}{l}\text { Vocational guidance No. } \\
M / 0509 / 2003 \text { on the standards } \\
\text { for the diagnosis and treatment } \\
\text { of drug dependencies }\end{array}$ & \\
\hline & $\begin{array}{l}\text { Decree } 158 / 2010 \text { of } 23 \text { March } \\
2010 \text { of the Ministry of Health } \\
\text { laying down formal } \\
\text { requirements for the book of } \\
\text { narcotic substances and keeping } \\
\text { records of narcotic substances } \\
\text { proving receipt and dispensing } \\
\text { of narcotic and psychotropic } \\
\text { substances }\end{array}$ & $\begin{array}{l}\text { Act. N. 147/2001 on Advertising } \\
\text { of Medicinal Products }\end{array}$ & & & \\
\hline \multirow{2}{*}{ 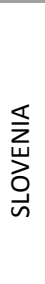 } & $\begin{array}{l}\text { Order on the Promulgation of the } \\
\text { Prevention of the Use of Illicit } \\
\text { Drugs and Dealing with } \\
\text { consumers of Illicit Drugs Act }\end{array}$ & $\begin{array}{l}\text { Rules on classifying, prescribing } \\
\text { and dispensing medicinal } \\
\text { products for human use }\end{array}$ & $\begin{array}{l}\text { Law on Health Care and Health } \\
\text { Insurance }\end{array}$ & & $\begin{array}{l}\text { The constitution of the Republic } \\
\text { of Slovenia }\end{array}$ \\
\hline & $\begin{array}{l}\text { Production of and Trade in Illicit } \\
\text { Drugs Act }\end{array}$ & & $\begin{array}{l}\text { Act(s) Amending the Health Care } \\
\text { and Health Insurance Act }\end{array}$ & & \\
\hline
\end{tabular}

\footnotetext{
${ }^{11}$ Although Act. N. 140/1998 has been replaced by Act. N. 362/2011, no important changes have been made to the parts that were indicated as relevant by the national counterpart. Therefore, Act. N. 140/1998 has been (partly) reviewed.
} 


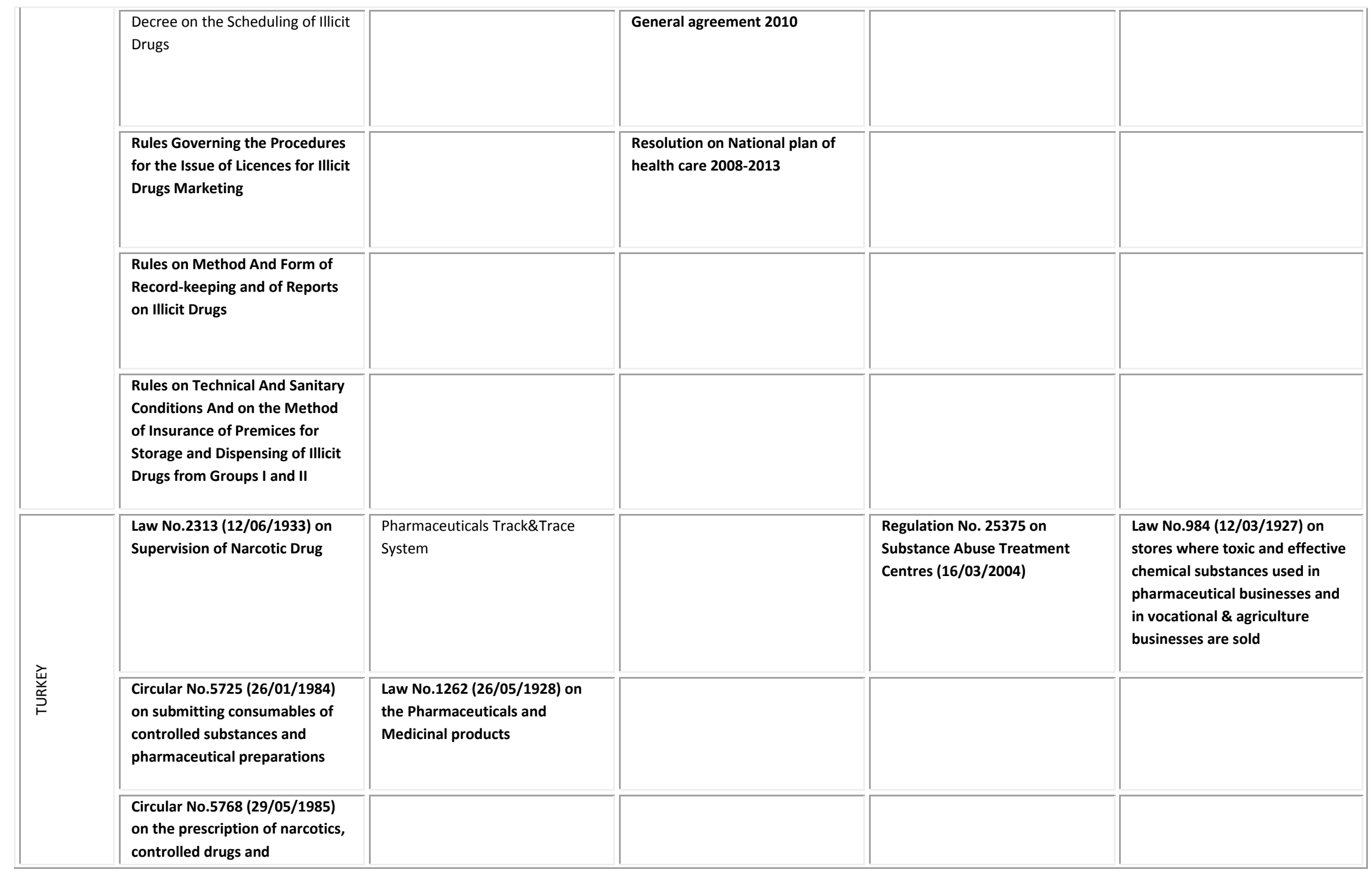




\begin{tabular}{|l|l|l|l|l|}
\hline preparations & & & \\
\hline $\begin{array}{l}\text { Circular No.09/2677 } \\
\text { (02/01/1986) }\end{array}$ & & & \\
\hline
\end{tabular}

Annex 2: Feedback form ATOME legislation review

\begin{tabular}{|l|}
\hline Feedback document: ATOME legislation review country report, country $\mathbf{X}$ \\
Date \\
\hline Is the reviewed legislation (paragraph 6.1) still valid? If not, please specify.... \\
\hline Are the translations correct? This is even more important for the translation of provisions that are identified \\
as potential barriers in the category 'language'. Please specify.... \\
\hline Are there any doubts or disagreements regarding the identification of potential barriers? Please specify.... \\
\hline Are there potential legal or regulatory barriers missing? Please specify... \\
\hline Are there any doubts or disagreements regarding the proposed recommendations? Please specify... \\
\hline Are there any recommendations missing that should be added? Please specify... \\
\hline Are there any other questions, comments or concerns we should take into account? Please specify... \\
\hline
\end{tabular}

